\title{
Utah Law Review
}

Volume 2014 | Number 2

Article 1

2014

\section{Speaking of Science: Introducing Notice and Comment into the Legislative Process}

Gregory Dolin

University of Baltimore School of Law

Follow this and additional works at: https://dc.law.utah.edu/ulr

Part of the Legislation Commons, and the Science and Technology Law Commons

\section{Recommended Citation}

Dolin, Gregory (2014) "Speaking of Science: Introducing Notice and Comment into the Legislative Process," Utah Law Review: Vol. 2014 : No. 2 , Article 1.

Available at: https://dc.law.utah.edu/ulr/vol2014/iss2/1

This Article is brought to you for free and open access by Utah Law Digital Commons. It has been accepted for inclusion in Utah Law Review by an authorized editor of Utah Law Digital Commons. For more information, please contact valeri.craigle@law.utah.edu. 


\title{
SPEAKING OF SCIENCE: INTRODUCING NOTICE AND COMMENT INTO THE LEGISLATIVE PROCESS
}

\author{
Gregory Dolin, M.D.*
}

\begin{abstract}
Congress enacts, on a nearly continuous basis, a variety of laws that affect scientific research and progress. Some of these laws have an unquestionably positive effect. For instance, Congress's creation of the National Institutes of Health, the National Academy of Sciences, and NASA; its various appropriations to fund ground-breaking research; and a multitude of other laws have incalculably advanced human knowledge, and it is to Congress's great credit that these laws have been and are continuing to be enacted. However, not all laws that affect the progress of sciences are an unalloyed good. Quite the opposite, often the laws aim to, and in fact do, retard the progress of scientific research. The question is then whether the benefit from those laws outweighs the costs imposed on scientific progress.

Congress, however, often does not fully consider the costs that the legislation imposes on science, either for lack of information or as a result of conscious disregard for the views of a politically insignificant group. The public is not able to hold Congress accountable because it lacks an ability to participate in the process and lacks an objective basis against which to measure congressional action. The problem is not congressional malfeasance or ignorance but rather the structure of the legislative process itself. The general public is often taught and told that lawmaking is a process that begins in a committee where the proposal is carefully studied, debated, amended, and voted on. The reality, of course, is much different. First, bills often skip the committee process, and amendments are often added last minute without a chance for a meaningful debate. But even where the process is followed, it is often hard to portray the committee hearings as a true deliberative process. Instead, they are often described as a Kabuki theater, where the Chair and the Ranking Member designate the witnesses they wish to call to support the preformulated position. Interested parties cannot provide testimony unless asked to do so by the relevant committee. Thus, oftentimes the people with the deepest knowledge, but low political skills,
\end{abstract}

* (C) 2014 Gregory Dolin. Associate Professor of Law, Co-Director, Center for Medicine \& Law, University of Baltimore School of Law. Adjunct Associate Professor of Emergency Medicine, The Johns Hopkins University School of Medicine. B.A., The Johns Hopkins University; J.D., Georgetown University Law Center; M.D., State University of New York at Stony Brook. I am thankful to Irina Manta, Erin Sheley, Tara Helfman, David Jaros, Will Hubbard, Ron Weich, and Teresa Woodruff for their comments and insight. 
are cut out of the process. The end result is that Congress votes on legislation without fully understanding the implication thereof. The voters also are injured in that it is hard to hold Congress accountable if one cannot point out that it ignored the views of the scientific communities.

This Article proposes a solution to the problem. Bills that affect the progress of science ought to be evaluated by an independent body similar to the Congressional Budget Office. Like the CBO, this body would not have any authority to block a bill, but it would be able to "score" it (i.e., provide information on the effect the bill will have on research). In order to accomplish its task, this newly created body would be required to provide notice of pending legislation and then seek comments from the interested parties, much like what is done in the administrative rulemaking process. The comments then would be collected and analyzed, and the final report would be presented to Congress before it votes. Congress would continue to be able to vote as it pleases, but with this process in place, it would be forced to do so with its eyes wide open. By understanding the full scope and the implication for the scientific progress of the bills it wishes to enact, Congress would produce better legislation, which would be less detrimental to the scientific progress.

\section{INTRODUCTION}

Otto von Bismarck is rumored to have quipped that "legislation is like sausage: it's better not to watch it being made." 1 It may well have been sound advice when the laws were made in service of a monarchy without much consideration of the views or desires of the populace. Americans, however, "have ignored this advice and have widely subscribed to the view that a truly democratic people must have access to governmental decision-making . . ." ${ }^{2}$ Yet, despite an expectation of public participation, in reality the public is often shut out from the legislative process. This exclusion creates three distinct though interrelated problems, especially when Congress legislates in areas that deal with science and technology. First, when Congress legislates in these areas, it tends to prove Bismarck correct because it legislates in the dark, without understanding the underlying issues or the full impact that legislation is likely to have on the progress

${ }^{1}$ Cheryl D. Block, Pathologies at the Intersection of the Budget and Tax Legislative Processes, 43 B.C. L. REV. 863, 870 n.28 (2002). The quote is likely apocryphal, but it is oft quoted by lawyers and judges alike, despite there being no definitive proof that Bismarck actually uttered these words. Alexander M. Sanders, Jr., Newgarth Revisited: Mrs. Robinson's Case, 49 S.C. L. REV. 407, 412 n.18 (1998).

${ }^{2}$ James Bowen, Behind Closed Doors: Re-Examining the Tennessee Open Meetings Act and Its Inapplicability to the Tennessee General Assembly, 35 Colum. J.L. \& Soc. PROBS. 133, 133 (2002). 
of sciences. ${ }^{3}$ Second, even when Congress is aware of the potential negative effect that the legislation will have on the progress of sciences, it often prefers not to acknowledge that effect, instead focusing on the benefits that the bill would bring to certain political constituencies. ${ }^{4}$ This lack of recognition of the negative effects in turn diminishes Congress's democratic accountability because Congress never faces a definitive warning about the scientific effects of its legislative activity. In other words, the fact that Congress ignored a warning from experts would allow the public to conclude that a law's negative effects were not "unintended consequences," but instead, a case of willful disregard of expert opinion. Third, the current legislative process tends to diminish trust in the system because the affected parties do not believe that they had opportunities to convey their concerns or that their concerns were considered. The solution, however, is not to avert our gaze, as Bismarck recommended, but to improve the process so that the result is as worthy as sausages are tasty.

Congress enacts, on a nearly continuous basis, a variety of laws that affect scientific research and progress. Some of these laws have an unquestionably positive effect. For instance, Congress's creation of the National Institutes of Health, ${ }^{5}$ the National Academy of Sciences (NAS), ${ }^{6}$ and NASA $;{ }^{7}$ its various appropriations to fund ground-breaking research; ${ }^{8}$ and a multitude of other laws have incalculably advanced human knowledge, and it is to Congress's great credit that these laws have been and are continuing to be enacted. However, not all laws that affect the progress of sciences are an unalloyed good. Quite the opposite, often

${ }^{3}$ See Cornelia Dean, Groups Call for Scientists to Engage the Body Politic, N.Y. TIMES, Aug. 9, 2011, at D1 ("[A]ccording to the Congressional Research Service, the technically trained among the 435 members of the House include one physicist, 22 people with medical training (including 2 psychologists and a veterinarian), a chemist, a microbiologist and 6 engineers.”).

${ }^{4}$ Cf. Megan Creek Frient, Note, Similar Harm Means Similar Claims: Doing Away with Davis v. Bandemer's Discriminatory Effect Requirement in Political Gerrymandering Cases, 48 CASE W. RES. L. REV. 617, 644-45 (1998) ("Since the incumbent from the politically gerrymandered district knows he or she represents an area which has been crafted so that a majority of the residents share his or her political views, the representative has no incentive to acknowledge other voters' concerns: Safe districts remove the incentive to grant political concessions to constituent interests or create electoral coalitions [that] ensure representation of diverse points of view. In fact, granting the minority party's point of view deference in a gerrymandered district would be foolish. The representative would risk offending the constituents whose support the district was designed to guarantee.” (alteration in original) (footnote omitted) (internal quotation marks omitted)).

${ }^{5}$ Ransdell Act, Pub. L. No. 71-251, 46 Stat. 379-80 (1930).

${ }^{6}$ Act to Incorporate The National Academy of Sciences, ch. 111, 12 Stat. 803, 806 (1863).

7 National Aeronautics and Space Act of 1958, Pub. L. No. 85-568, 72 Stat. 426 (current version at 51 U.S.C. § 20103 (Supp. IV 2010)).

${ }^{8}$ See, e.g., Consolidated Appropriations Act, 2012, Pub. L. No. 112-74, 125 Stat. 786 (2011); Consolidated Appropriations Act, 2004, Pub. L. No. 108-199, 118 Stat. 3 (2004). 
the laws aim to, and in fact do, retard the progress of scientific research. ${ }^{9}$ The question is, then, whether the benefit from those laws outweighs the costs imposed on scientific progress. At one extreme, consider the Nuclear Test Ban Treaty. ${ }^{10}$ The treaty certainly had the effect of limiting the study of nuclear physics. ${ }^{11}$ Yet, there is some value in banning nuclear tests, and Congress has attempted to strike a balance between the two. ${ }^{12}$ The problem is that too many laws are enacted without any serious consideration of these costs and benefits because these laws are written and passed without the full understanding or acknowledgment of the impact that they will have on scientific research. ${ }^{13}$

These problems can be ameliorated by furnishing unbiased scientific analysis to Congress, provided that such analysis is furnished in a language that is both neutral and comprehensible to an average member of Congress. Members of Congress, of course, would not be obliged to change their vote on the basis of any particular report, but the very presence of such a report would provide a solid political basis on which to evaluate the member's commitment to science and scientific progress. Furthermore, to the extent that Congress deliberately rejects

${ }^{9}$ See Steven Goldberg, The Reluctant Embrace: Law and Science in America, 75 GEO. L.J. 1341, 1366 (1987) ("To give examples of legal restrictions on technology is to survey much of modern American law. ... Food and drug law has become recognized as a discrete area of study that includes cases where new products have been delayed in reaching the market or prevented from doing so altogether. In other areas, ranging from communications to computers, regulation is a fact of modern life. At the state level, statutes and judicial decisions, concerning, for example, malpractice, products liability, and exposure to radioactive materials, have subjected technology to extraordinarily close scrutiny.”).

${ }^{10}$ Treaty Banning Nuclear Weapon Tests in the Atmosphere, in Outer Space and Under Water, Aug. 5, 1963, 14 U.S.T. 1313, 480 U.N.T.S. 43.

${ }^{11}$ See Winston P. Nagan \& Erin K. Slemmens, Developing U.S. Nuclear Weapons Policy and International Law: The Approach of the Obama Administration, 19 TUL. J. INT'L \& COMP. L. 41, 76 (2010) (“[T]he nuclear weapons problem is one that deeply implicates science and technology. A relevant role from modern international law is to come to grips with the possibilities and limitations of science and technology in order to provide the goal guidance that is both relevant and steeped in realism.”); Eric Schmitt, Experts Say Test Ban Could Impair Nuclear-Arms Safety, N.Y. TiMES, Oct. 8, 1999, at A11.

${ }^{12}$ For example, the United States ratified the 1963 Nuclear Test Ban Treaty, supra note 10, but balked at ratifying the new Comprehensive Nuclear Test Ban Treaty. See 145 CONG. REC. 25,143 (1999) (rejecting the Treaty by a vote of forty-eight to fifty-one). One of the reasons for the opposition to the Treaty was the stated effect on scientific testing. See Schmitt, supra note 11.

${ }^{13}$ See Valerie M. Fogleman, Regulating Science: An Evaluation of the Regulation of Biotechnology Research, 17 ENVTL. L. 183, 191-92 (1987) ("Scientists argue that risks of experimentation in biotechnology cannot be discussed rationally unless participants understand the subject matter. . . . According to many scientists, rapidly-moving research simply is not amenable to safety regulations by nonscientific decision makers. . . . Public participants in scientific discussions tend to be intimidated by scientists, and are hesitant to raise technical issues for fear of embarrassment.” (footnotes omitted)). 
warnings provided in any such analysis, the judiciary will be able to better evaluate whether Congress actually meant to reach what may in a vacuum be viewed as "absurd results." ${ }^{14}$ In other words, if Congress actually considered a particular result and determined that the occurrence of such a result is not problematic, the courts would then be hard pressed to hold that this very result is "absurd." This Article proposes the creation of an advisory body - the Congressional Scientific Office-that would be able to provide unbiased scientific advice to members of Congress with respect to any pending bill or amendment. Such an advisory body would greatly improve the legislative process, as well as have a beneficial effect on the ability of the public to hold their elected representatives accountable for the votes these representatives cast.

Part II discusses what the general public often learns about the lawmaking process versus the actual reality of the process. According to civics textbooks, the lawmaking process begins in a committee where the proposal is carefully studied, debated, amended, and voted on. Then, the process is repeated on the floor of the House of Representatives and then again, from scratch, in the Senate. The reality, of course, is much different. First, bills often skip the committee process, and amendments are often added last minute without a chance for a meaningful debate. But even where the process is followed, it is often hard to portray the committee hearings as a true deliberative process. Instead, they are often described as a Kabuki theater, ${ }^{15}$ where the chair and the ranking member designate the witnesses they wish to call to support the preformulated position. ${ }^{16}$ Interested parties cannot provide testimony unless asked to do so by the relevant committee. ${ }^{17}$ Thus,

${ }^{14}$ See generally Church of the Holy Trinity v. United States, 143 U.S. 457 (1892) (engaging in statutory interpretation by looking at the implicated statute's words and viewing Congress's petitions and testimony behind the statute in order to analyze whether the congressional intent of the statute was the actual result or if such a result was absurd).

${ }^{15}$ See Caprice L. Roberts, Discretion \& Deference in Senate Consideration of Judicial Nominations, 51 U. LouisviLle L. ReV. 1, 6 (2012). While most criticisms focus on nomination, especially judicial nomination hearings, legislative hearings are little different. See infra notes 34-37 and accompanying text.

${ }^{16}$ Lisa O. Monaco, Comment, Give the People What They Want: The Failure of "Responsive” Lawmaking, 3 U. CHI. L. SCH. RoundTABLE 735, 761-62 (1996) (“Because of the unique control that committee chairs have over the design and content of hearingsincluding who testifies and on what-testimony at hearings may be viewed as simply an additional forum for interest group influence in the form of witnesses. It is up to the chair to decide the extent to which individuals will be heard by the committee or to which their written views will be placed in the committee record. . . In general, the committee chair retains power to set the agenda and format of any hearings and determine all witnesses in consultation with the ranking member of the minority party on the committee.”).

${ }^{17}$ See Clay Calvert, The First Amendment, the Media and the Culture Wars: Eight Important Lessons From 2004 About Speech, Censorship, Science and Public Policy, 41 CAL. W. L. REV. 325, 341-47 (2005) (describing a hearing on adult industry where only scientists opposed to pornography were invited to participate, but those holding contrary views or questioning the basis of the studies presented to the committee were not); Peter DiCola \& Matthew Sag, An Information-Gathering Approach to Copyright Policy, 34 
oftentimes, the people with the deepest knowledge are cut out of the process, ${ }^{18}$ either because their views do not fit the preformulated agenda or because the information they convey cannot, in any event, be processed by nonexpert congressmen. The end result is that Congress votes on legislation without fully understanding the implications thereof. ${ }^{19}$ The voters are also injured because it is hard to hold Congress accountable if one cannot point out that it ignored the views of the scientific communities. ${ }^{20}$

Part III discusses a specific example of uninformed legislating and its effect on scientific progress. The Dickey-Wicker Amendment was enacted in 1996 as part of the annual appropriation process. ${ }^{21}$ The Amendment bars federal funding for any research on a human embryo, which is in turn defined as any organism "derived by fertilization, parthenogenesis, cloning, or any other means from one or more human gametes." 22 This rider was enacted without any separate vote on the issue and was attached to "must-pass" legislation. ${ }^{23}$ It has been reenacted every year since $1996 .{ }^{24}$ The problem is that in enacting this legislation, no one considered whether differences between fertilization, cloning, and parthenogenesis exist, and if so, whether they are of sufficient magnitude to treat each process differently. ${ }^{25}$ As it turns out, such differences do exist, ${ }^{26}$ yet they were not taken

CARDOZO L. REV. 173, 189 (2012) ("[T]he information Congress receives . . . is limited by the set of parties invited to participate.”).

${ }^{18}$ Cf. Monaco, supra note 16, at 762 ("[W]itnesses reflecting minority viewpoints are often heard from last and end up speaking to few Members and empty hearing rooms.”).

${ }^{19}$ See Fogleman, supra note 13, at 189-92.

${ }^{20}$ Lotte E. Feinberg, Open Government and Freedom of Information: Fishbowl Accountability?, in HANDBOOK OF PUBLIC LAW AND ADMINISTRATION 375-77 (Philip J. Cooper \& Chester A. Newland eds., 1997) (stating that for electoral accountability, "citizens must have access to information about what their government is doing and how decisions have been reached"); see also Joseph S. Alonzo, Restoring the Ideal Marketplace: How Recognizing Bloggers as Journalists Can Save the Press, 9 N.Y.U. J. LEGIS. \& PUB. POL'Y 751, 752 (2006) (“Broad availability of information is an essential element of a strong democracy-quality collective decision-making and electoral accountability both depend upon an informed polity.”).

${ }^{21}$ Balanced Budget Downpayment Act, Pub. L. No. 104-99, § 128, 110 Stat. 26, 34 (1996)

${ }^{22} I d$.

${ }^{23}$ See Omnibus FY96 Bill Ties Loose Ends, in 52 Cong. Q. AlmanAC, at 10-5, 10-19 (1996) (discussing the background of the 1996 Omnibus Appropriations).

${ }^{24}$ O. Carter Snead, Science, Public Bioethics, and the Problem of Integration, 43 U.C. DAVIS L. REV. 1529, 1546 (2010).

${ }^{25}$ As discussed in Part III, the bill was written, considered, passed, and signed within forty-eight hours, leaving essentially no time to debate the merits of any of its provisions. See Bill Summary \& Status, 104th Congress (1995-1996), H.R. 2880, LIBRARY OF CONGRESS, http://thomas.loc.gov/home/LegislativeData.php?\&n=BSS\&c=104 (search "Balanced Budget Downpayment Act, I" and select first link).

${ }^{26}$ See generally Sarah Rodriguez et al., An Obscure Rider Obstructing Science: The Conflation of Parthenotes with Embryos in the Dickey-Wicker Amendment, 11 AM. J. BIOETHICS 20 (2011) (describing how parthenogenesis is scientifically and ethically 
into account, precisely because no one asked the right question, there was no one in the room to answer it, and perhaps the sponsors of legislation did not want to hear the answer. The Dickey-Wicker Amendment has stymied research in areas such as fertility, assisted reproductive technologies, and stem cells, all because of Congress's basic lack of understanding of the underlying scientific principles. ${ }^{27}$

Part IV of the Article proposes a solution to the problem. Bills that affect the progress of science ought to be evaluated by an independent body similar to the Congressional Budget Office. ${ }^{28}$ Like the CBO, this body would not have any authority to block a bill, but it would be able to "score" it (i.e., provide information on the effect the bill will have on research). ${ }^{29}$ In order to accomplish its task, this newly created body would be required to provide notice of pending legislation and then seek comments from the interested parties, much like what is done in the administrative rulemaking process. ${ }^{30}$ The comments would then be collected and analyzed with the final report presented to Congress before it votes. Congress will continue to be able to vote as it pleases, but with this process in place, it will be forced to do so with its eyes wide open. By understanding the full scope and the implication for the scientific progress of the bills it wishes to enact, Congress will produce better legislation, which will be less detrimental to scientific progress. If representatives choose to ignore the opinions of experts, voters will be able to hold their representatives accountable.

\section{The Legislative PROCESS: Myths AND REAlities}

Millions of Americans think of the legislative process by reference to Schoolhouse Rock's I'm Just a Bill ${ }^{31}$ and Jimmy Stewart's Mr. Smith Goes to Washington. ${ }^{32}$ The process that is imprinted in the public's mind is one with exhaustive debates in the committees and on the floor, where the views of people, most likely to be affected by the legislation and most knowledgeable in the subject matter, provide input to Congress before a congressional determination is made. ${ }^{33}$ This view is bolstered by congressional webpages that list committees and their areas of jurisdiction, congressional mailings touting a particular individual's

different from fertilization and cloning and that Congress should consider removing parthenogenesis from the Dickey-Wicker Amendment).

${ }^{27}$ See id.

${ }^{28}$ For the history and the description of the functions of the Congressional Budget Office, see generally CONG. Budget OfFICE, AN INTRODUCTION TO THE CONGRESSIONAL BUDGET OFFICE (2012) [hereinafter INTRODUCTION], available at http://www.cbo.gov/sites/ default/files/cbofiles/attachments/2012-IntroToCBO.pdf (last visited Feb. 28, 2014).

${ }^{29}$ See id. at 1-3.

${ }^{30}$ See 5 U.S.C. $§ 553$ (2006) (describing the notice-and-comment process within the administrative agencies).

${ }^{31}$ Schoolhouse Rock!: I'm Just a Bill (ABC television broadcast 1975), available at http://www.youtube.com/watch?v=FFroMQlKiag.

${ }^{32}$ Mr. SMith GoES to WASHINGTON (Columbia Pictures Corp. 1939).

${ }^{33}$ See, e.g., Schoolhouse Rock!: I'm Just a Bill, supra note 31. 
membership on a certain committee that is supposedly relevant to the specific concerns of the congressman's district, and even C-SPAN programming that shows committee hearings where congressmen and senators hear testimony and question proponents and opponents of proposed bills. With such media presentations, the public can be forgiven for thinking that each bill undergoes serious scrutiny and debate before being voted on and enacted into law. The reality, however, is quite different.

In the last few years, congressional hearings have often been called "Kabuki theater" ${ }^{34}$ or a "dog and pony show." ${ }^{35}$ While the moniker is most often applied to the judicial confirmation hearings, ${ }^{36}$ the same is true about all other hearings. ${ }^{37}$ The hearings are no longer designed to elicit unbiased expert testimony to aid the deliberative process, but rather to provide support for preexisting political viewpoints. ${ }^{38}$ The appearance of witnesses in the congressional hearings is not a matter of right for the public, but a matter of prerogative for committee chairs and ranking members. ${ }^{39}$ The chairman is a particularly powerful figure in the committee with the authority to decide not only which proposals are considered and in what order (or for that matter whether they are considered at all), but also which witnesses he will call and to what they will testify. ${ }^{40}$

The exercise of this power was on display when the late Senator Jesse Helms, the then-Chairman of the Senate Foreign Relations Committee, refused to hold hearings on the nomination of William Weld to be the U.S. Ambassador to

${ }^{34}$ See, e.g., Nelson Lund, Judicial Independence, Judicial Virtue, and the Political Economy of the Constitution, 35 HARV. J.L. \& PUB. POL'Y 47, 59 (2012); Editorial, How Conservative Is Judge Roberts?, N.Y. TIMES, Sept. 15, 2005, at A30 (quoting then-Senator Joe Biden describing the hearings as a "Kabuki dance").

${ }^{35}$ Indiana State Bar Association Conference on Relations Between Congress and the Federal Courts: A Stenographic Record, 41 IND. L. REV. 305, 327 (2008) [hereinafter Indiana State Bar] ("I find this for me more helpful than a congressional hearing and what some would call a dog and pony show, which is what a lot of the hearings turn out to be.") (quoting Congressman Brad Ellsworth); Michael A. McCann, Antitrust, Governance, and Postseason College Football, 52 B.C. L. REV. 517, 541 n.147 (2011) (describing some congressional hearings on sports investigation as "dog-and-pony shows" created to attract media attention).

${ }^{36}$ See supra note 34.

${ }^{37}$ See Indiana State Bar, supra note 35.

${ }^{38}$ See supra notes $16-17$ and accompanying text.

${ }^{39} \mathrm{Id}$.

40 Nathaniel O. Keohane et al., The Choice of Regulatory Instruments in Environmental Policy, 22 HARV. ENVTL. L. ReV. 313, 344-45 n.99 (1998) ("Power is particularly concentrated in the hands of committee chairs, who hold sway over the committees' agendas and the bills reported to the floor."); see also Richard H. Pildes \& Elizabeth S. Anderson, Slinging Arrows at Democracy: Social Choice Theory, Value Pluralism, and Democratic Politics, 90 Colum. L. REV. 2121, 2137 (1990) (noting that committee chairs control the agenda and that "[t]he rules for setting the agenda become a powerful means for manipulating a divided legislature to converge on those outcomes favored by the agenda setters"). 
Mexico. ${ }^{41}$ When Senator Helms's Republican colleagues rebelled against this approach, Senator Helms was forced to hold a hearing. ${ }^{42}$ However, at that hearing, it was not Governor Weld who testified in support of his nomination. ${ }^{43}$ Rather, Senator Helms engaged in a soliloquy about the Senate traditions of allowing the committee chairmen to refuse to bring up matters for hearings or votes and then adjourned the hearing when he was done. ${ }^{44}$

A committee chairman also has the authority to draft a bill on his own and have that bill form the basis of discussions, rather than what may have been debated in a subcommittee or during the initial hearings in the full committee. ${ }^{45}$ Thus, the chairman has a near complete control of the scope and substance of discussion that takes place in the committee. ${ }^{46}$

The modern absurdity of committee hearings is perhaps best illustrated by the appearance of the comedian Stephen Colbert in front of the House Judiciary Committee in September of $2010 .^{47}$ Mr. Colbert used the opportunity to mock Congress and the process of considering bills. ${ }^{48} \mathrm{Mr}$. Colbert, however, did not just arrive at the hearing room unannounced. He was invited by the subcommittee Chair, the long-serving Representative Zoe Lofgren. ${ }^{49}$ Instead of a real debate on the merits of the Farm Bill, the committee (and by extension, the public) was treated to a mocking performance of a satirist. ${ }^{50}$

${ }^{41}$ Richard L. Berke \& Steven Lee Myers, In Washington, Few Trifle with Jesse Helms, N.Y. TiMES, Aug. 2, 1997, http://www.nytimes.com/1997/08/02/us/in-washingtonfew-trifle-with-jesse-helms.html?pagewanted=all\&src=pm.

${ }^{42}$ Katharine Q. Seelye, With Iron Gavel, Helms Rejects Vote on Weld, N.Y. TIMES, Sept. 13, 1997, at A1.

${ }^{43} \mathrm{Id}$.

${ }^{44}$ Ultimately, Governor Weld was never brought up for a vote, and his nomination was withdrawn. William Neikirk, Weld Whiffs on Helms Hardball, CHI. TRIB., Sept. 16, 1997, at 1 .

${ }^{45}$ See Glossary of Congressional Terms > C, THECAPITOL.NET, http://www.thecap itol.net/glossary/c.htm\#Chairman'sMark/Staff Draft (defining “Chairman's Mark” as a "[r]ecommendation by committee (or subcommittee) chair of the measure to be considered in a markup, usually drafted as a bill”) (last visited Feb. 28, 2014).

${ }^{46}$ See supra note 40.

${ }^{47}$ C-SPAN: Stephen Colbert's Opening Statement (C-SPAN 3 television broadcast Sept. 24, 2010), available at http://www.youtube.com/watch?v=k1T75jBYeCs.

${ }^{48}$ See id.; see also Jonathan Allen, Colbert Knocks Dems Off Message, Politico.CoM (Sept. 24, 2010, 4:57 PM), http://www.politico.com/news/stories/0910/42692.html ("David Corn, who writes for the liberal Mother Jones magazine, tweeted 'Colbert is making a mockery of this hearing.' Republicans were more harsh.").

${ }^{49}$ Nicole Allan, Stephen Colbert Testifies in Congress, in Character, THE ATLANTIC (Sept. 24, 2010, 12:07 PM), http://www.theatlantic.com/politics/archive/2010/09/stephencolbert-testifies-in-congress-in-character/63507/.

${ }^{50}$ See Michael D. Shear \& Ashley Parker, The Caucus; A Comic Twist On Political Chatter, N.Y. TimES, Sept. 25, 2010, http://query.nytimes.com/gst/fullpage.html?res=950D E1D71231F936A1575AC0A9669D8B63. 
What's more, committee hearings are rarely fully attended by the committee members. ${ }^{51}$ In some ways, this is not surprising given that each member of Congress serves on a number of committees. ${ }^{52}$ The supposed deliberations then are actually quite often just a show, with most of the work done not out in the open by the people responsible to the electorate, but by the staffers. ${ }^{53}$ While staffers may consult with experts in the field, ${ }^{54}$ they need not do so, and even when they do consult-because whatever advice is obtained comes through private communications-there is little chance to test these communications against criticism and opposing viewpoints. ${ }^{55}$ Instead, the more likely outcome is epistemic closure where the preplanned political outcome is justified by reference to selective presentation of information and arguments. ${ }^{56}$ Congressional committees then are not the deliberative and fact-finding bodies portrayed in Schoolhouse Rock videos, but rather are rubber-stamps for prewritten bills. Indeed courts have often disregarded congressional findings of fact ${ }^{57}$ precisely because quite often

${ }^{51}$ Caitlin E. Borgmann, Rethinking Judicial Deference to Legislative Fact-Finding, 84 IND. L.J. 1, 41 (2009) ("The very conduct of the committee hearings undermines any serious examination of the facts; attendance is often poor, and during the testimony legislators frequently talk to one another, wander in and out to take phone calls, and engage in side conversations with their staff.").

${ }^{52}$ Marvin C. Ott, Partisanship and the Decline of Intelligence Oversight, 16 INT’L J. INTELLIGENCE \& COUNTERINTELLIGENCE 69, 87 (2003) (noting that members of Congress "have multiple committee assignments and, under the best of circumstances, have difficulty giving adequate time and attention to any one of them").

${ }^{53}$ See, e.g., William L. Andreen, Beyond Words of Exhortation: The Congressional Prescription for Vigorous Federal Enforcement of the Clean Water Act, 55 GEO. WASH. L. REV. 202, 237 (1987) ("The Committee, however, had not completed the final text of the bill and left the task of drafting the appropriate language to its staff."); Edward L. Rubin, Legislative Methodology: Some Lessons from the Truth-in-Lending Act, 80 GEO. L.J. 233, 285 (1991) ("The drafting can be done by the legislator's own staff, as Truth-in-Lending was, or by a centralized staff of one kind or another, such as committee counsel, legislative counsel, or a separate research office ....").

${ }^{54}$ See Lloyd Hitoshi Mayer, What Is This "Lobbying" That We Are So Worried About?, 26 YALE L. \& POL’y REV. 485, 552 (2008) (“Members of Congress and their staffs are most vulnerable to the problematic methods because of their reliance on reelection, the often temporary nature of their government service, and their ability to have closed door meetings with lobbyists that protect the information they receive from outside scrutiny." (footnote omitted)); Victoria F. Nourse \& Jane S. Schacter, The Politics of Legislative Drafting: A Congressional Case Study, 77 N.Y.U. L. REV. 575, 584 (2002) (relating a staffer's experience of "reworking a long-pending constitutional amendment drafted in consultation with legal scholars, policy experts, and representatives of law enforcement").

${ }_{55}$ See Neal Devins, Why Congress Did Not Think About the Constitution when Enacting the Affordable Care Act, 106 Nw. U. L. ReV. ColloQuy 261, 266-67 (2012) (noting that the minority party is often unable "to call witnesses or otherwise define the hearing agenda”); Mayer, supra note 54, at 552.

${ }^{56}$ See Mayer, supra note 54, at 552.

${ }^{57}$ See, e.g., U.S. v. Morrison, 529 U.S. 598, 615 (2000) (rejecting Congress’s findings of fact and noting that they "are substantially weakened by the fact that they rely so heavily 
these findings are tendentious, open to much dispute, and sometimes are not even supported by actual evidence. ${ }^{58}$

This situation would be bad enough, but that is merely the beginning of failures in the legislative process. Several additional factors ensure the bills that come up for votes on the floor of each house are not subject to full debate, scrutiny, and relevant data. In the House of Representatives, before being reported to the floor, each bill has to be considered and reported by the Committee on Rules. ${ }^{59}$ Whereas the various committees with subject matter jurisdiction are at least nominally specialized-with representatives assigned based on specific interest in the matters within committee's jurisdiction and staffers being drawn from the pool of individuals with specialized knowledge in these matters-the Rules Committee is a purely political tool designed to allow the Speaker of the House to keep control of the bills brought to the floor. ${ }^{60}$ The Rules Committee's power over all bills is nearly limitless:

The [Rules] Committee has the authority to do virtually anything during the course of consideration of a measure, including deeming it passed. The Committee can also include a self-executed amendment which could rewrite just parts of a bill, or the entire measure. In essence, so long as a majority of the House is willing to vote for a special rule, there is little that the Rules Committee cannot do. ${ }^{61}$

Despite this power, the Committee does not spend much time considering the bills that it reports to the floor. ${ }^{62}$ Nor does it often hear outsiders' testimony. ${ }^{63}$ Instead, the individuals testifying before the Rules Committee are usually other members of Congress that urge the committee to allow (or disallow) consideration of certain amendments on the House floor. ${ }^{64}$ Despite the lack of deep familiarity or the factual background behind the bills, the Rules Committee can-and doesrewrite bills it considers, even when such bills have been painstakingly developed

on a method of reasoning that we have already rejected as unworkable if we are to maintain the Constitution's enumeration of powers”).

${ }^{58}$ See Borgmann, supra note 51, at 40.

59 See About the Committee on Rules-History and Processes, U.S. HOUSE OF REPRESENTATIVES, COMM. ON RULES, http://rules.house.gov/about (last visited Feb. 28, 2014).

${ }^{60}$ See id.

${ }^{61}$ Id.

${ }^{62}$ See id.

${ }^{63}$ See id. ("Rules Committee holds a hearing where the witnesses are the Members of the House who sit on the committee of jurisdiction or want to offer amendments.”).

${ }^{64}$ See id. 
in the committee of jurisdiction. ${ }^{65}$ This makes the final product even less deliberative and more political-in the worst sense of the word. ${ }^{66}$

The Senate does not have a counterpart to the House Rules Committee. ${ }^{67}$ Nonetheless, the Senate has its own methods of skirting committees of jurisdiction. The Senate majority leader controls the Senate's calendar. ${ }^{68}$ The majority leader decides when to call up each bill, irrespective of whether it has been fully vetted (or for that matter, vetted at all) by the committee of jurisdiction. ${ }^{69}$ In other words, a bill can be written, introduced, and then immediately called up for consideration, thus bypassing any hearings or opportunity — such as it is — for interested members of the public to offer their views and criticism. ${ }^{70}$ To be fair, the Senate rules do allow senators to force extended-and nearly limitless-debate on any bill, thus providing a bit of a safety check against bills being rushed through without due consideration. ${ }^{71}$ That said, the length of the debate and speechifying-often to an otherwise empty chamber ${ }^{72}$ - does not necessarily enhance the quality of the debate or allow experts, individuals, or groups most affected by the proposed legislation to offer their views or describe the likely effect the proposed legislation will have.

Related to the aforementioned problems is the fact that Congress has, over the decades, blurred the traditional line between authorizing legislation and

${ }^{65}$ See Gerald B.H. Solomon \& Donald R. Wolfensberger, The Decline of Deliberative Democracy in the House and Proposals for Reform, 31 HARV. J. ON LEGIS. 321, 358-63 (1993); U.S. HOUSE OF REPRESENTATIVES, COMM. ON RULES, supra note 59.

${ }^{66}$ See generally Solomon \& Wolfensberger, supra note 65 (asserting that current congressional policy-making practices are breaking down the basis of deliberative democracy).

${ }^{67}$ The Senate does have a Committee on Rules and Administration, but its jurisdiction is significantly narrower than that of its House counterpart. The Senate Committee deals only with the administration of the Senate itself, as well as bills on a specific and rather limited basis. See About the Committee, COMM. ON RULES \& ADMIN., http://www.rules.sen ate.gov/public/index.cfm?p=PurposeJurisdiction (last visited Feb. 28, 2014).

68 Valerie Heitshusen, Cong. Research Serv., CRS Report 96-548, The Legislative Process on the SENATE FlOOR: An INTROduction 5 (2013), available at http://www.senate.gov/CRSReports/crs-publish.cfm?pid=\%26*2D4Q\%5CK3\%0A ("The Senate gives its majority leader the primary responsibility for deciding the order in which bills on the calendar should come to the floor for action.”).

${ }^{69} \mathrm{Id}$. at 6.

${ }^{70} I d$. (noting that Senate Rule XIV allows any senator to bypass referral to committee, but because the majority leader controls the calendar, that power is only effective with respect to the bills that the majority leader wishes to have debated on the floor).

${ }^{71}$ See Standing Rules of the Senate r. XXII, in COMm. ON RULES \& ADMIN., SENATE MANuAL, S. Doc. No. 112-1, r. XXII, at 1, 20-22 (2011). This is the rule that permits the process known as filibuster as it allows the debate to be shut off only if three-fifths of the elected senators vote to end debate. Id.

72 See Stuart Banner, Trials and Other Entertainment, 55 ST. LouIS U. L.J. 1285, 1288 (2011) ("On C-Span today, you can watch politicians giving speeches before what look like completely empty chambers.”). 
appropriating legislation. Professor Richard Lazarus describes the distinction between the two types of bills and the consequences that flow from each:

The decision whether to pass authorizing legislation, such as the Clean Air Act, its detailed amendments, or any other kind of substantive legislation, is almost always entirely discretionary. Because relatively few federal statutes ... have sunset provisions, congressional failure to pass a new authorization statute preserves the status quo. The absence of legislative action does not create a disruptive legal vacuum. Congress need not formally reauthorize either the Clean Water Act or the Clean Air Act after a statutorily prescribed number of years for those laws to remain in effect. Hence, those seeking to pass a new authorization statute invariably face the heavy burden of demonstrating why a change is necessary.

Precisely the converse is true when appropriations legislation is at stake. There is enormous political pressure to pass annual appropriations legislation because, absent its passage, the status quo is not maintained. Instead, there is a very real threat of a complete shutdown of the federal government. If the deadline for the annual appropriations bill is not met, then to avoid a shutdown Congress must at a minimum pass a continuing resolution to appropriate funds for a few more weeks or months as necessary to keep an agency in operation until passage of the annual appropriations bill. ${ }^{73}$

As a result of the "must-pass" nature of the appropriation bills, "it is tempting to try to attach incidental provisions that otherwise might lack the political momentum (or even majority support) necessary for passage." 74 These riders can often be no different than stand-alone "substantive" bills, but because they are attached to appropriation bills, rather than authorization legislation, they are not considered in the committee of jurisdiction over the substantive matter. If they are considered in the committee at all, it is in the Committee on Appropriations. ${ }^{75}$ Quite often, these riders are not even considered in the Appropriations Committee, but rather are added last minute during the floor debates and votes. ${ }^{76}$ Again, in either case, the legislators are deprived of the considered views of those whom the legislation is likely to affect. ${ }^{77}$

${ }^{73}$ Richard J. Lazarus, Congressional Descent: The Demise of Deliberative Democracy in Environmental Law, 94 GEO. L.J. 619, 634-35 (2006).

${ }^{74} \mathrm{Id}$. at 635.

${ }^{75}$ See id. at 636. Of course, any rider that is part of the annual appropriations bill would expire at the same time as the underlying bill would. Thus, such riders would have to be renewed from year to year if they are to continue in force.

${ }^{76}$ See id. at $648-53$.

${ }^{77}$ See id. 
A final stage at which bills can be amended without much public input or debate is a conference committee formed to negotiate over different versions of a bill passed by the House and the Senate. ${ }^{78}$ Much like the House of Representative's Committee on Rules, conference committees have an almost unlimited authority to rewrite or modify a pending bill, ${ }^{79}$ and they can do so in near-total secrecy, ${ }^{80}$ for meetings of conference committees are generally not open to the public, at least not for the purposes of giving testimony and illuminating the full scope of effects that the bill (or any modifications thereto) would have. ${ }^{81}$

In short, the informed, deliberative process that the public is taught to expect is quite often anything but that. Instead, the process is often much more haphazard, ill-informed, and subject to hijacking by individuals who may not understand the full impact of the very legislation for which they support and vote. Furthermore, the current process allows congressmen to obscure and obfuscate politically inconvenient facts. By refusing to bring forth witnesses, Congress can create legislative history that is willfully barren of countervailing facts. In those situations, the problem is not that congressmen do not understand the implications of the legislation, but that they willfully refuse to acknowledge those implications.

This degradation of the deliberative process has several effects. It results in legislators being presented with limited and incomplete information and, consequently, congressmen voting on bills without fully realizing the downside of their votes. These votes may well be cast differently if information presented were

78 See THECAPITOL.NET, supra note 45 (“A temporary, ad hoc panel composed of House and Senate conferees that is formed for the purpose of reconciling differences in legislation that has passed both chambers.”).

79 See, e.g., Oliver A. Houck, Things Fall Apart: A Constitutional Analysis of Legislative Exclusion, 55 EMORY L.J. 1, 11-12 (2006) (describing how a conference committee rewrote the 2003 Medicare bills, including reinserting the language previously rejected in floor votes); Victor M. Sher \& Carol Sue Hunting, Eroding the Landscape, Eroding the Laws: Congressional Exemptions from Judicial Review of Environmental Laws, 15 HARV. ENVTL. L. ReV. 435, 443-44 (1991) ("The bill went to the Senate Appropriations Energy-Water Subcommittee, where the second Tennessee senator, Jim Sasser, left the language intact. The full Senate voted to remove Duncan's language from the bill, but after the conference committee concluded, the bill returned to the Senate with the Tellico exemption again present. The senators, now weary of the issue, voted to allow the dam to be completed." (footnotes omitted)).

${ }^{80}$ See, e.g., id. at 11 (describing that the conference committee excluded not only the public, but even members of Congress with opposing viewpoints); Jameel Jaffer, Secret Evidence in the Investigative Stage: FISA, Administrative Subpoenas, and Privacy, 5 CARdozo Pub. L. PoL'y \& ETHICS J. 7, 15 (2006) (“The conference committee... [dealing with a Patriot Act reauthorization] met only once, and only so that members could deliver opening statements. 'The rest of the work of the conference committee consists of Republican staff working behind the scenes to draft a compromise bill. . . . That is to say that the Republican staff of the Senate negotiated with the Republican staff of the House."” (quoting Rep. Jerry Nadler)).

${ }^{81}$ See, e.g., Sher \& Hunting, supra note 79, at 477-78. 
more complete. ${ }^{82}$ That said, the linkage is not always true. It may well be that congressmen would vote the same way no matter how much information were available and how many people testified in front of their committee. Congressmen may aim to please their political supporters and discount the costs that such legislation may impose on the rest of society. ${ }^{83}$ Additional information or broadening the spectrum of participants in the legislative process is unlikely to change legislators' basic incentives. ${ }^{84}$ What additional information may do, however, is focus congressmen's attention on the broader effect that the legislation will have, beyond merely pleasing political allies. Once such effects are brought into focus, congressmen at least would have to justify their decision to ignore these effects, while the electorate will be able to pass judgment on whether such justifications withstand scrutiny. The next Part provides a glaring example of how these problems affect legislation and cause injury to the progress of science.

\section{THE DICKEY-WICKER AMENDMENT}

\section{A. The Amendment and Its History}

The above discussion is not meant to suggest that the legislative process is either irreparably broken or that the process itself is worthless. Indeed, with respect to most matters addressed by the legislature, the legislative process works the way it is intended to. Much of what Congress does centers on value judgments about the appropriate role of government, level of taxation, proper foreign policy, etc. ${ }^{85}$

${ }^{82}$ See Kenneth C. Smurzynski, Modeling Campaign Contributions: The Market for Access and Its Implications for Regulation, 80 GEO. L.J. 1891, 1899 (1992).

${ }^{83}$ See Lindsay Warren Bowen, Jr., Note, Givings and the Next Copyright Deferment, 77 FordHAM L. REV. 809, 821 (2008) (discussing Congress's response to "small, politically powerful group of copyright holders," despite the fact that such a response "harms society by allowing copyright holders to charge artificially high prices and by restraining the creation of new works based on copyrighted material"); Thomas O. Sargentich, The Future of the Item Veto, 83 IowA L. REV. 79, 122 (1997) ("The electoral system is often singled out as the key source of relevant institutional incentives for politicians, given the assumption that the President and members of Congress will inevitably seek to reward the constituencies that elected them. . . The pressure on members of Congress is particularly intense when the benefits of a governmental policy are concentrated and the costs are spread widely among members of the public, for in such cases, private interests have a strong motivation to organize to seek benefits.").

${ }^{84}$ See Sargentich, supra note 83, at 122 (noting that because of reelection concerns, "members of Congress will inevitably seek to reward the constituencies that elected them").

${ }^{85}$ George Jiang, Rain or Shine: Fair and Other Non-Infringing Uses in the Context of Cloud Computing, 36 J. LEGIS. 395, 395 (2010) ("[E]very statute encapsulates legislative value judgments regarding foreseeable situations at the time of enactment.”); see also Dr. Anja Seibert-Fohr, The Rise of Equality in International Law and its Pitfalls: Learning from Comparative Constitutional Law, 35 BROOK. J. INT’L L. 1, 38 (2010) ("Whether 
In those circumstances, congressional majorities are primarily concerned with building public support for their proposed public policy solutions. ${ }^{86}$ In that posture, the "dog and pony" congressional hearings make perfect sense. The hearings there are not meant to illuminate the issues for debate, but rather to bolster the political support for (or to drum up opposition to) a preformulated political position. ${ }^{87}$

Congress, in making its decisions, does have to rely on its understanding of the facts as they exist in the real world. When the facts are common or undisputed knowledge (e.g., the distance between two cities, the number of days in a year, or the revenues and expenditures of the government in the years past), there is not much danger that Congress will misunderstand the content, scope, or the import of the factual basis (though, of course, it may choose to assign whatever weight it chooses to these facts). However, when the facts concern complicated scientific issues requiring specialized knowledge for full comprehension, congressmen, usually untrained in science, are unlikely to fully understand either the predicate for their actions or the full effect that the actions will have. ${ }^{88}$ As a result, Congress often enacts laws that have a devastating effect on the speed and scope of scientific progress. It does so not out of any malice for scientific advances, but out of misunderstanding of the issues.

The Dickey-Wicker Amendment ("DWA") ${ }^{89}$ is a perfect example of Congress acting without understanding the full effect that the legislation would have on scientific exploration. Since 1974, federal law had already imposed restrictions on the use of federal funds with respect to fetal research. ${ }^{90}$ Those restrictions have been part and parcel of the abortion debate and legislative skirmishes. ${ }^{91}$ In the

legislation is generally reasonable largely depends on value judgments that vary from nation to nation.”).

${ }^{86}$ See, e.g., Joseph A. Castelluccio III, Sarbanes-Oxley and Small Business: Section 404 and the Case for a Small Business Exemption, 71 BRoOK. L. REv. 429, 435-36 (2005) ("In order to enact effective securities regulation on the federal level, the Pecora Hearings sought to "galvanize[] broad public support for direct federal regulation of the stock markets." (alteration in original) (quoting JOEL SELIGMAN, THE TRANSFORMATION OF WALL STREET: A HISTORY OF THE SECURITIES AND EXCHANGE COMMISSION AND MODERN CORPORATE FINANCE 2 (3d ed. 2003)).

${ }^{87}$ See Castelluccio III, supra note 86, at 436.

${ }^{88}$ See, e.g., Alfred J. Cote, Jr., Who Tells Congress About Technology?, InDUs. RESEARCH, Sept. 1967, at 78, 80 (noting that scientists are "unable to translate their ideas into language that Congressmen understand").

${ }^{89}$ Pub. L. No. 104-99, § 128, 110 Stat. 26, 34 (1996).

${ }^{90}$ See Public Health Service Act, Pub. L. No. 93-348, § 213, 88 Stat. 342, 353 (1974) (codified at 42 U.S.C. 289I-1 (1978), repealed by Community Mental Health Centers Extension Act of 1978, Pub. L. No. 95-622, § 302(b), 92 Stat. 3442 (1978) (limiting fetal research by prohibiting support for research on a living human fetus unless done for the survival of the fetus).

91 See Gary L. Reback, Fetal Experimentation: Moral, Legal, and Medical Implications, 26 STAN. L. REV. 1191, 1207 (1974) ("Roe produced a rash of hastily prepared . . . statutes designed to prohibit the same type of fetal experimentation that had occurred prior to recent liberalized abortion laws.”). 
1990s, however, as scientific horizons began to expand and the research began to focus on the earliest stages of human development, the ethical and political concerns over such research began to extend not just to fetal tissue, but also to embryonic tissue. The issue was studied by the National Institute of Health's ("NIH") Human Embryo Research Panel, composed of nineteen leading scientists and ethicists. ${ }^{92}$ The panel issued its report on September 27, 1994, and recommended making federal funding available for research using "spare" embryos, embryos obtained from consenting IVF patients, embryos created specifically for research, and research using parthenotes. ${ }^{93}$ This Part discusses the science of parthenotes and why the distinction is important, despite being overlooked by Congress. President Clinton declined to follow the recommendation in full, and under the executive order issued in 1994, federal funding was not made available for embryos created specifically for research. ${ }^{94}$ What is interesting about President Clinton's executive order was that it was made after a period of study, comments, and a report by a body of experts. ${ }^{95}$ Nevertheless, the fact that the President did not fully endorse the recommendations of the expert panel does not diminish the importance of having had the benefit of the expert input.

Congress, however, was not satisfied with President Clinton's compromise. In response, in 1996, it enacted the DWA. ${ }^{96}$ The DWA prohibited funding for any research that involved "(1) the creation of a human embryo or embryos for research purposes; or (2) research in which a human embryo or embryos are destroyed, discarded, or knowingly subjected to risk of injury or death . . ."97 The DWA defined "human embryo" as "any organism ... . that is derived by fertilization, parthenogenesis, cloning, or any other means from one or more human gametes." ${ }^{98}$ Although Congress, like the President, had access to the NIH

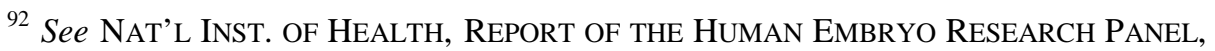
at vii-viii (1994), available at http://bioethics.georgetown.edu/pcbe/reports/past_commissi ons/human_embryo_vol_1.pdf.

${ }^{93}$ Id. at xviii-xix.

${ }^{94}$ Debora Spar \& Anna Harrington, Selling Stem Cell Science: How Markets Drive Law along the Technological Frontier, 33 AM. J.L. \& MED. 541, 556 (2007) (“On the very same day that the NIH approved the report, however, President Clinton issued an executive order forbidding the use of federal funds for embryo research in which embryos were created or destroyed.”).

${ }^{95} I d$.

${ }^{96}$ See Rodriguez et al., supra note 26, at 24-25 ("The momentum for a more inclusive ban, however, began a month earlier, when, in the 1994 elections, Republicans regained control of both Congressional houses. For many of those elected, Clinton's prohibition was not enough.”).

${ }^{97}$ Balanced Budget Downpayment Act, Pub. L. No. 104-99, § 128, 110 Stat. 26, 34 (1996); see also Omnibus Appropriations Act, 2009, Pub. L. No. 111-8, § 509, 123 Stat. 524, 803 (prohibiting use of funds available under this appropriations act for the same purposes); Departments of Labor, Health and Human Services, and Education, and Related Agencies Appropriations Act, 2006, Pub. L. 109-149, § 509, 119 Stat. 2833, 2880 (2005).

98 Balanced Budget Downpayment Act § 128; see also Omnibus Appropriations Act 2009, Pub. L. No. 111-8, § 509, 123 Stat. 524, 803 (including the "human diploid cells” 
Report, there is no evidence that it ever considered the findings of the report or the distinctions drawn therein. The reason is that the DWA, because it was a "rider" on a must-pass appropriations bill, ${ }^{99}$ was never debated in any committee or on the floor. Instead, it was attached to a bill that resolved the "longest federal government shutdown in American history." "100 The entire Act was introduced, debated, and voted on in the House of Representatives in fewer than two and a half hours. ${ }^{101}$ The Senate considered the entirety of the bill, including three separate amendments (none of which dealt with embryonic research) and voted on it the next day. ${ }^{102}$ President Clinton signed it immediately upon the Senate's passage. ${ }^{103}$ This legislative rider has been reenacted every year since. ${ }^{104}$ As with the initial enactment, there is no evidence that the amendment was ever debated in any committee or on the floor of either house.

The DWA and its restrictions became particularly salient in 1998 with the discovery of a successful method to isolate and grow human embryonic stem cells using cell culture. ${ }^{105}$ Embryonic stem cells are a potential treasure trove of future research and treatment. ${ }^{106}$ Three different presidents have had to issue contradictory statements on NIH funding of such research. ${ }^{107}$ The most recent NIH

language); Departments of Labor, Health and Human Services, and Education, and Related Agencies Appropriations Act, 2006, Pub. L. 109-149, § 509, 119 Stat. 2833, 2880 (2005) (inserting the language "human diploid cells" after "human gametes”).

99 See Omnibus FY96 Bill Ties Loose Ends, supra note 23, 10-19.

100 See Rodriguez et al., supra note 26, at 25 (discussing the attachment of the DWA to the LHHS budget stalls).

${ }^{101}$ See LIBRARY OF CONGRESS, supra note 25.

102 See id.

${ }^{103} \mathrm{Id}$.

104 Kiyan Bigloo, Aggregation of Powers: Stem Cell Research and the Scope of Presidential Power Examined Through the Lens of Executive Order Jurisprudence, 18 PSYCHOL. PUB. POL’Y. \& L. 519, 523 (2012).

105 See John A. Robertson, Procreative Liberty in the Era of Genomics, 29 AM. J. L. \& MED. 439, 483 (2003) ("The right-to-life versus scientific research fault-line surfaced again in debates over federal funding of embryonic stem cell research. That debate began in 1998 when researchers at Johns Hopkins University and the University of Wisconsin developed ways to culture human embryonic stem cells indefinitely in the laboratory, opening the door to directing them to produce replacement tissue to treat disease.”).

106 See id.; Shannon McGuire, Embryonic Stem Cells: Marrow of the Dickey Matter, 11 J. High TECH. L. 160, 160 (2010) (discussing the therapeutic potential of human embryonic stem cells).

107 Compare Presidential Statement on Federal Funding of Research on Human Embryos, 30 Weekly Comp. Pres. Doc. 2459 (Dec. 2, 1994) (statement by President Clinton refusing to allocate federal funds "to support the creation of human embryos for research purposes”), with Presidential Address to the Nation on Stem Cell Research from Crawford, Texas, 37 Weekly Comp. Pres. Doc. 1149, 1151 (Aug. 9, 2001) (statement by President Bush allocating funds for limited human embryo research), and Exec. Order No. 13,505, 74 Fed. Reg. 10,667 (2009) (President Obama's order to remove restrictions and expand federal funding for embryo research). 
policy, one enacted pursuant to President Obama's executive order, ${ }^{108}$ has been challenged in courts as contravening DWA's clear statutory language. ${ }^{109}$ The D.C. Circuit disagreed that the language was sufficiently clear to allow only one interpretation, thus permitting the challenged regulations to stand. ${ }^{110}$ The point is that because Congress never debated the DWA, it has never made a record as to what evils it was meant to prevent, leaving each administration somewhat free to adopt broad or narrow interpretation of the law and to fund or not fund various research projects. This, of course, is highly detrimental to the scientific community, which, as a result, is plagued by uncertainty over whether research will continue to be funded or whether the change in administration will result in a funding cutoff. With scientific progress dependent on long-term research projects, this state of affairs is hardly ideal.

\section{B. The Science of Parthenotes}

The DWA is part of the perennial fight and debate over abortion and the question of when life actually begins. ${ }^{111}$ To be sure, these are not scientific issues and are not amenable to any falsifiable experimentation. ${ }^{112}$ As the U.S. Supreme Court pointed out, even "those trained in the respective disciplines of medicine, philosophy, and theology are unable to arrive at any consensus" as to when life begins. ${ }^{113}$ In that sense, the DWA's effect on science and scientific exploration is secondary to its proponents. ${ }^{114}$ Nonetheless, even those who espouse the view that life begins at conception and merits protection from that point in time do not generally take the view that research on any cell that contains the full complement of human chromosomes is improper. ${ }^{115}$ Indeed, opponents of abortion and embryonic research often tout research on human nonembryonic cells as a viable

${ }^{108}$ Exec. Order No. 13,505, 74 Fed. Reg. 10,667 (2009).

${ }^{109}$ Sherley v. Sebelius, 644 F.3d 388, 393-94 (D.C. Cir. 2011).

${ }^{110} I d$. at 390, 396-97.

${ }^{111}$ See June Mary Zekan Makdisi, The Slide from Human Embryonic Stem Cell Research to Reproductive Cloning: Ethical Decision-Making and the Ban on Federal Funding, 34 RUTGERS L.J. 463, 475-78 (2003) (discussing the enactment of the DickeyWicker Amendment as part of the effort to "to uphold the sanctity and intrinsic value of life, and to prevent the dehumanization and commodification of human life").

${ }^{112}$ See Lauren R. Robbins, Open Your Mouth and Say 'Ideology': Physicians and the First Amendment, 12 U. PA. J. CONST. L. 155, 183-86 (2009) (discussing lack of scientific consensus on the question of when life begins).

${ }^{113}$ Roe v. Wade, 410 U.S. 113, 159 (1973).

${ }^{114}$ See Makdisi, supra note 111, at 475 ("Congress voiced its response as a rider to the appropriations bill and made it clear that beneficence to the embryo rather than utility to the populace should be the governing value.”).

${ }^{115}$ See, e.g., Gregory Dolin, A Defense of Embryonic Stem Cell Research, 84 IND. L.J. 1203, 1210 n.56 (2009) (discussing the support of various religious groups for adult stem cell research); James J. McCartney, Embryonic Stem Cell Research and Respect for Human Life: Philosophical and Legal Reflections, 65 ALB. L. REV. 597, 623-24 (2002) (noting that there is "little ethical debate" about the use of adult stem cells). 
alternative to embryonic research. ${ }^{116}$ The reason for treating embryos (even single cell ones) differently from other cells with full chromosomal complement is the notion that embryos, given enough time and the right environment, can develop into full adult human organism, whereas other cells cannot do so. It is for this reason that the two sets of cells that would otherwise look nearly identical under the microscope are accorded a different moral status. ${ }^{117}$ The moral and philosophical aspects of this valuation, however, are undergirded by a purely factual scientific inquiry: Can this particular cell develop into an adult human organism? If so, then, and only then, does it stand on a higher moral plane. ${ }^{118}$ Thus, in order to make that judgment, an individual needs to be familiar with the answers to certain basic scientific questions. Unfortunately, the Congress that enacted the DWA (and subsequent Congresses) never considered this issue when they enacted the broad funding prohibition that covered research on parthenotes. ${ }^{119}$ Had Congress understood the nature and the science of parthenotes and parthenogenesis, the scope of the DWA may have well been narrower, and the effect on scientific exploration less pronounced.

Parthenogenesis is a portmanteau ${ }^{120}$ derived from Greek parthenos, meaning virgin, and genesis, meaning birth. ${ }^{121}$ The term is used to denote asexual reproduction. ${ }^{122}$ Unlike sexual reproduction that involves the contribution of genetic materials from both an egg and a sperm, parthenogenesis involves contribution from the egg only. ${ }^{123}$ This form of reproduction is naturally occurring

${ }^{116}$ See id.

117 See Allison C. Ayer, Stem Cell Research: The Laws of Nations and a Proposal for International Guidelines, 17 CONN. J. INT’L L. 393, 399 (2002) ("Proponents of th[e] view [that embryos have the same moral status as humans], including many Roman Catholics, believe that when genetic material is joined there is a unique potential for life, therefore the embryo holds independent moral status and should have the same rights that all living people have." (emphasis added) (footnote omitted)); Heather Johnson Kukla, Note, Embryonic Stem Cell Research: An Ethical Justification, 90 GEO. L.J. 503, 517-18 (2002) (stating that the reason for much of the opposition to embryonic research stems from the fact that "some view embryos as human persons with the same moral status as adults and children”).

118 See id. ("Proponents believe that the embryo's potential to develop into a human person confers upon it full moral status as a person ....”" (emphasis added)).

119 Balanced Budget Downpayment Act, Pub. L. No. 104-99, § 128, 110 Stat. 26, 34 (1996).

120 Lewis Carroll, Through the LoOKing Glass, and What Alice Found THERE 67 (Selwyn Hugh Goodacre \& James Russell Kincaid eds., University of California Press 1983) ("You see it's like a portmanteau-there are two meanings packed up into one word.”).

${ }^{121} \mathrm{Id}$.

122 Erez Aloni, Symposium, From Page to Practice: Broadening the Lens for Reproductive and Sexual Rights: Cloning and the LGBTI Family: Cautious Optimism, 35 N.Y.U. REV. L. \& SOC. CHANGE 1, 56 n.268 (2011).

${ }^{123}$ Rodriguez et al., supra note 26, at 21. 
and is common to a number of invertebrate species. ${ }^{124}$ It is also present in all classes of vertebrates, excepting mammals. ${ }^{125}$ In nonmammals, this form of reproduction "can occur spontaneously (i.e., naturally) as a continuous reproductive strategy or as a response to environmental or nutritional changes.”"126 In mammals (of which humans are, of course, part), spontaneous parthenogenesis cannot result in a viable full-term offspring because this form of reproduction has been, evolutionary speaking, abandoned. ${ }^{127}$ Instead, when mammalian ova get spontaneously activated, they result not in an offspring, but in an ovarian tumor. ${ }^{128}$ Thus, spontaneous parthenogenesis can occur in humans, but it is not a genesis or birth of a new life, but rather of cancerous lesions. ${ }^{129}$

Parthenotes (defined as ova activated via parthenogenesis) also can be created in vitro "through chemical stimuli that mimic fertilization, but the lack of required genetic imprinting rules out further development." ${ }^{30}$ These "activated" ova begin to divide as if they were fertilized, but the division is halted at an early stage of cell differentiation, eventually resulting in the death of the parthenote. ${ }^{131}$ Thus, human parthenotes, whether created spontaneously in vivo or during the course of an experiment in vitro, intrinsically are incapable of becoming viable human embryos. ${ }^{132}$ Their potential for developing into an adult organism is no greater than the potential of an unfertilized egg or a tumor cell. Yet, despite this obvious difference between parthenotes and embryos, the DWA treats them as one and the same, and it does so without anyone in Congress ever explicitly considering this difference. $^{133}$

While parthenotes are not a perfect research substitute for embryos, they do have their valuable uses. First, because parthenotes do involve the initial activation of an ovum, they can be used to study the early stages of pregnancy and embryonic development. ${ }^{134}$ For instance, it has been reported that implantation of fertilized eggs as part of Assisted Reproductive Technology (“ART”) processes often fail because the egg activation process does not function properly. ${ }^{135}$ Studying the intricacies of that process would help perfect ART processes and ultimately lead to higher rate of success with in vitro fertilization and, therefore, less abandoned or "spare" embryos. ${ }^{136}$

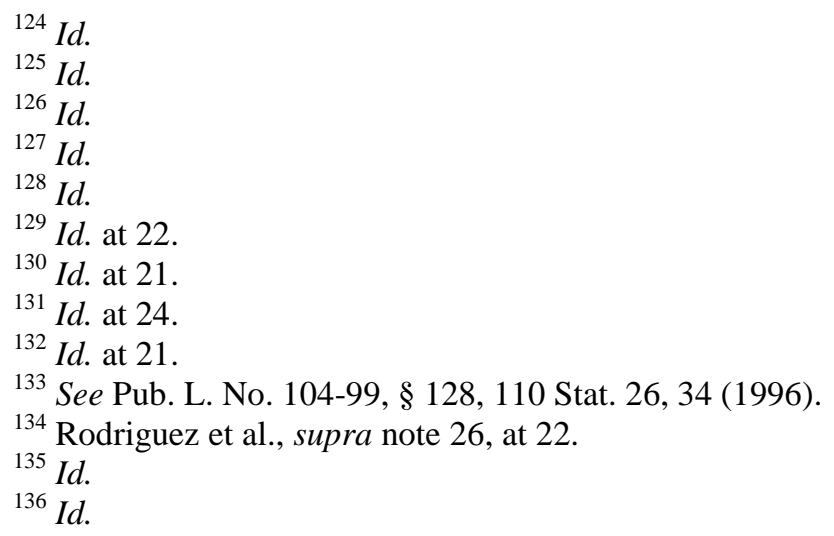


Second, parthenotes are useful in studying miscarriages. ${ }^{137}$ Some research suggests that many miscarriages are due to the "very early loss of nonviable parthenotes caused by spontaneous egg activation in the female." ${ }^{138}$ Identifying a biological marker that differentiates parthenotes from fertilized ova would help study the causes of miscarriage. ${ }^{139}$

Third, parthenotes are useful in studying certain tumors. ${ }^{140}$ As mentioned previously, in mammals, spontaneous in vivo parthenogenesis leads not to an offspring, but to a gonadal tumor. ${ }^{141}$ Despite tremendous advances in knowledge about cancer causes and treatments, it is still one of the most complicated diseases from the viewpoint of its etiology, diagnosis, and progression, as well as its treatment. ${ }^{142}$ Any advances in understanding cancer processes, its diagnosis, and treatment would be valuable for the preservation of both extant human life, as well as potential human life, by helping to preserve fertility in the affected population.

Finally, parthenotes may serve as a source of stem cells akin to those extracted from embryos. ${ }^{143}$ It is generally believed that stem cell research can lead to breakthrough advances in the understanding and treatment of spinal cord injuries, Alzheimer's disease, Parkinson disease, and a number of other ailments. ${ }^{144}$ Whereas extraction of embryonic stem cells generally involves destroying an embryo, thus raising the concerns about the destruction of potential viable human life, ${ }^{145}$ extraction of similar stem cells from parthenotes avoids these concerns because, as discussed previously, human parthenotes are never viable and will not, under any circumstances, develop into an adult human. ${ }^{146}$ Thus, parthenotes can be a point of compromise between proponents of full federal funding for embryonic stem cell research and opponents of such funding.

All of these advances are now precluded because of the broad language of the Dickey-Wicker Amendment-a provision that was enacted with no debate and no understanding of the crucial biological differences between embryos and parthenotes.

This Article does not take a specific position on the propriety of embryonic or parthenote research ${ }^{147}$ because the ultimate outcome of legislative debate is not where the problem lies. After all, on any contentious issue, after the votes are

${ }^{137} \mathrm{Id}$.

${ }^{138} \mathrm{Id}$.

${ }^{139} \mathrm{Id}$.

${ }^{140} \mathrm{Id}$.

${ }^{141}$ See supra notes 128-129 and accompanying text.

142 See Gina Kolata, In Long Drive to Cure Cancer, Advances Have Been Elusive, N.Y. TiMES, Apr. 24, 2009, at A1.

${ }^{143}$ Rodriguez et al., supra note 26, at 22.

144 Molly Silfen, How Will California's Funding of Stem Cell Research Impact Innovation? Recommendations for an Intellectual Property Policy, 18 HARV. J. LAW \& TECH. 459, 468 (2005).

${ }^{145}$ Dolin, supra note 115, at 1215.

146 See supra notes 130-132 and accompanying text.

${ }^{147}$ For my views on the embryonic research, see generally Dolin, supra note 115. 
counted, one side has to win, and the other has to lose. That has to happen even if there has been the most exhaustive and informative of debates. The point is not that the decision on the DWA necessarily should have been different either in whole or in part. It may very well be that even after hearing all of the arguments and scientific data differentiating parthenotes from embryos, Congress still would have enacted the DWA in its present form. One reason Congress could have done so is to create a "fence of protection" around human life, much like Talmudic scholars impose requirements on observant Jews that go beyond the bare minimum commands of the Torah, so as to make sure that the actual precepts are not violated. ${ }^{148}$ Second, it is quite possible that even given an identical set of facts, people of different political and religious persuasions, after viewing the facts through their own lens, will come to radically different conclusions as to what is the "right solution"149 and, therefore, choose not to fund parthenotes research. Third, it may well be that the political incentives of the DWA's proponents are such that they weigh heavily towards voting for the broadest possible ban irrespective of the cost imposed on scientific progress. ${ }^{150}$

Ultimately, what form a decision on the DWA would have taken and whether such decision would have been a good one from the perspective of public policy is not what concerns me. Rather, my argument is that the decision, whatever it is, must be made after the legislators are fully apprised of the scientific underpinnings of their proposals and the likely effect that the proposal would have on the progress of sciences. In this way, congressmen would understand the full implication of their actions, and the public would be able to judge those actions against the complete set of facts. The next Part suggests how to ensure that this informational and deliberative part of the decision-making process actually occurs.

148 See The Mishnah: A New Translation 672 (Jacob Neusner trans., 1988); Stephen J. Werber, Cloning: A Jewish Law Perspective with a Comparative Study of Other Abrahamic Traditions, 30 SetON HALl L. ReV. 1114, 1114 n.1 (2000) (discussing the Talmudic principle specifically in the context of cloning debate).

${ }^{149}$ See generally Dan M. Kahan \& Donald Braman, Cultural Cognition and Public Policy, 24 YAle L. \& POL'y ReV. 149 (2006) (explaining the epistemic origins of political conflict arising from cultural commitments that are prior to factual beliefs on highly charged political issues).

150 Nevertheless, the DWA was continued even when both chambers of Congress and the White House were controlled by the Democratic Party-the party generally less sympathetic to antiabortion and related legislation. Thus, it is unlikely that the Amendment can be explained purely by the desire of congressmen to please the politically allied antiabortion groups. 


\section{The CONGRESSiOnAl SCIENCE OfFICE AND LEGISLATIVE Notice AND COMMENT PROCESS}

\section{A. The Congressional Science Office}

As Part II previously discussed, there are three distinct, major problems with congressional decision making, especially when it affects science. First, there is a lack of an independent, nonpartisan forum for discussing and evaluating proposals. Second, there is a lack of sufficient training in the subject matter of proposals to fully understand their scope; and third, there is no meaningful ability for the public to contribute to the debate and discussion of the proposals. Thus, any system designed to fix the current flaws would necessarily have to address each of these shortcomings. Luckily, there are systems currently in place that can be used as models for addressing the shortcomings in congressional deliberations when it comes to scientific issues. Specifically, the role and function of the Congressional Budget Office is a useful point of departure in creating a nonpartisan body of experts to advise Congress on specific and technical matters for which congressmen themselves may not have full appreciation.

The Congressional Budget Office ("CBO”) was created in 1974 by the Congressional Budget Act to provide "independent analyses of budgetary and economic issues to support the Congressional budget process. The agency is strictly nonpartisan and conducts objective, impartial analysis . ..."151 The CBO "produce[s] a formal cost estimate for nearly every bill that is 'reported' (approved) by a full committee of either House of Congress . . .." "152 The CBO also provides an annual report called "Budget and Economic Outlook," which "includes projections of spending and revenues under current law over the next 10 years as well as an economic forecast . . .."153 Thus, the CBO evaluates not only likely prospective effects of proposed legislation, but also yearly reevaluates the effect of current policy and estimates the effect of these policies if they are continued. ${ }^{154}$ Finally, the CBO "prepares analytic reports at the request of the Congressional leadership or Chairmen or Ranking Minority Members of committees or subcommittees." 155 These reports analyze proposals that may or may not be in a form of a formal bill or amendment but help congressmen evaluate ideas that are being discussed either formally or informally. ${ }^{156}$

In producing its reports, the $\mathrm{CBO}$ relies on the internal government data available from agencies like the Census Bureau, Federal Bureau of Labor Statistics, Bureau of Economic Analysis, Bureau of Justice Statistics, etc. ${ }^{157}$

${ }^{151}$ CBO, INTRODUCTION, supra note 28, at 1.

${ }^{152} I d$. at 6.

${ }^{153}$ Budget and Economic Outlook, CONG. BUDGET OFFICE, https://cbo.gov/topics/bud get/budget-and-economic-outlook (last visited Feb. 28, 2014).

${ }^{154} \mathrm{CBO}$, INTRODUCTION, supra note 28 , at 1-2.

${ }^{155} \mathrm{Id}$. at 6.

${ }^{156} I d$. at 2, 9.

${ }^{157}$ See id. at 6. 
Government agencies, however, are not the sole source of information for the CBO. A particularly interesting aspect of CBO's operation is that it "seeks input from outside experts, including professors, analysts at think tanks, private-sector experts, and employees at various government agencies." ${ }^{158}$ This input “complement[s] the knowledge and insights of . . . the agency's staff."159

The CBO reports are not "binding" on Congress in a sense that an unfavorable CBO "score" (i.e., a report that projects that a given proposal would increase the deficit) does not preclude Congress from adopting the proposed bill. ${ }^{160}$ Indeed, Congress often votes to enact bills that increase the deficit. ${ }^{161}$ Nonetheless, the CBO reports are discussed during the committee and floor debates, as well as during election campaigns. ${ }^{162}$ As a result, the politicians, even when they ultimately decide to enact a law that is unfavorably scored by the CBO, must take that score into account and come up with coherent arguments as to why they voted the way they did. ${ }^{163}$

Though there has been some criticism of the CBO's methods, ${ }^{164}$ the CBO is generally viewed as a nonpartisan body, not beholden to either political party. ${ }^{165}$ Indeed, despite the criticism leveled at the CBO, it is generally viewed as a neutral

${ }^{158} \mathrm{Id}$.

160 Tim Westmoreland, Standard Errors: How Budget Rules Distort Lawmaking, 95 GEO. L.J. 1555, 1578 (2007) ("In principle, Budget Committee chairmen could ignore the CBO score or the Congress could amend its own rules or the Budget Act to allow the legislative amendment of a CBO score or to allow a PAYGO-violating measure to proceed without a supermajority.").

161 See, e.g., Gramm-Rudman-Hollings: Forgotten, But Not Yet Gone, 44 ConG. Q. WEEKLY REP. 2526, 2526 (1986) ("Despite the requirements [of the Gramm-Rudman Act], Congress took little notice of the CBO-OMB report.”).

162 See, e.g., David M. Herszenhorn, Wrangling Over Stimulus Is One-Sided So Far, N.Y. TIMES, Jan. 16, 2008, at A15 (noting the political effect of a CBO report on various stimulus proposals); Transcript of Debate Between Bush and Kerry, with Domestic Policy the Topic, N.Y. TIMES, Oct. 14, 2004, at A22 (quoting Senator John Kerry relying on CBO scoring to criticize President George W. Bush’s Social Security reform plans).

163 See, e.g., Bruce Bartlett, The Fiscal Legacy of George W. Bush, N.Y. TIMES: ECONOMIX (June 12, 2012, 6:00 AM), http://economix.blogs.nytimes.com/2012/06/12/the-f iscal-legacy-of-george-w-bush/ (describing different political justifications used to support tax cuts enacted during the Bush Administration, despite the unfavorable CBO score).

164 See, e.g., John W. Lee, Critique of Current Congressional Capital Gains Contentions, 15 VA. TAX REV. 1, 72-73 ("Capital gains proponents have argued that both the Joint Committee on Taxation and the Congressional Budget Office have historically erred in calculating capital gains revenues. Opponents of dynamic scoring, on the other hand, argue that CBO estimates of revenue gains from new tax provisions have tended to err on the high side . . . ." (footnote omitted)); Westmoreland, supra note 160, at 1574 (stating "work done by the CBO is credible and subject to intense review and criticism by interested parties .... .").

165 See Robert W. Hahn, Achieving Real Regulatory Reform, 1997 U. CHI. LEGAL F. 143, 153 (noting that the CBO "has a reputation for impartiality"). 
arbiter of budgetary disputes ${ }^{166}$ (even if certain political actors disagree with the underlying methodology). ${ }^{167}$ The CBO's estimates are often the centerpiece of political and campaign debates, and members of both parties rely on them to tout their own agenda or to criticize their opponents' plans. ${ }^{168}$ The CBO ensures that it remains a neutral arbiter (and is perceived as such) by limiting the political activities of its staff, ${ }^{169}$ requiring that the Speaker of the House and President pro tempore of the Senate appoint the Director of the Office after consultations with the members of the committees having jurisdiction over the budgetary matters, ${ }^{170}$ giving the Director a fixed four-year term (irrespective of the political vicissitudes of the individuals originally responsible for the Director's appointment), ${ }^{171}$ and seeking input from a variety of outside experts. ${ }^{172}$ Additionally, and perhaps most importantly, the CBO makes no policy recommendations to Congress. ${ }^{173}$ Instead, the CBO's role is limited to evaluating and scoring congressional policy proposals. $^{174}$

The CBO model is a good starting point for the creation of a system that would illuminate and evaluate congressional proposals that would have an effect on the progress of sciences. If Congress had a Congressional Science Office with a mission similar to that of a CBO, except on matters of science, the debates over legislation having impact on scientific progress would be better informed and more substantive. Indeed, there used to exist a similar congressional office. From 1972 to 1995, the Office of Technology Assessment (“OTA") produced studies on a wide range of topics from acid rain, to payment for physician services, to wood use. ${ }^{175}$ The new Republican majority abolished the OTA in 1995 as part of the

${ }^{166} \mathrm{Id}$.

${ }^{167}$ Westmoreland, supra note 160, at 1574 ("The near-constant carping by dissatisfied members of Congress, interest groups, or journalists that the CBO estimates are 'wrong' misses the point of the exercise. The CBO score is deemed to be correct by the agreements on how the budget process is to work, and all legislative rules and actions follow from it.” (emphasis in original)).

168 See Kevin M. Stack \& Michael P. Vandenbergh, The One Percent Problem, 111 ColuM. L. REV. 1385, 1426 (2011) ("Congress created the Congressional Budget Office and required the CBO to calculate the costs incurred over a four year period by each bill or joint resolution reported by any committee of the House or Senate. . . . The point of these disclosure requirements was to furnish Congress with detailed information concerning the budget consequences of proposed legislation so that its budget consequences form part of the legislative debate, and to provide an external measure of the budget consequences of enacted legislation.”); see also supra note 162 and accompanying text.

${ }^{169} \mathrm{CBO}$, INTRODUCTION, supra note 28, at 12.

${ }^{170}$ Id. at 4.

${ }^{171} \mathrm{Id}$.

${ }^{172}$ Id. at 6.

${ }^{173}$ Id. at 7.

${ }^{174}$ See id.

${ }^{175}$ For an exhaustive list of OTA publications, searchable by topic, see generally OTA Publications, OfFICE OF TECH. Assessment ARCHIVE, http://ota.fas.org/otareports/ (last visited Feb. 28, 2014); see also Albert C. Lin, Technology Assessment 2.0 Revamping Our 
Contract with America. ${ }^{176}$ The abolition of the office was criticized at the time, ${ }^{177}$ and there have been calls to resurrect it. ${ }^{178}$ A resurrected OTA would indeed be a good point of departure. However, the "new OTA," or Congressional Science Office ("CSO"), should have a somewhat different mission from the original OTA.

The original Office prepared reports on scientific issues of the day but without being tied to any specific legislation. ${ }^{179}$ Such reports are certainly useful as background information and as prods for Congress to act on issues that they might not have otherwise considered. Nonetheless, for individuals lacking scientific or technical training (like most congressmen), ${ }^{180}$ applying the background information to the specific legislative proposals is often just as difficult as acquiring the background knowledge in the first place. ${ }^{181}$ For that reason, the recreated office would be more effective if its reports were directed to specific legislative proposals, rather than general scientific issues that may be of interest to Congress and the country. On a related note, an office that chooses on its own which subject matters to report is more open to the accusation of political bias. ${ }^{182}$ Even when the science found in the report is sound and the conclusions drawn are true, the very act of selecting on which topics to report — and, therefore, highlight in the public's mind-and which to omit may create an impression that certain issues are being given more importance for political reasons. ${ }^{183}$ That is especially

Approach to Emerging Technologies, 76 BROOK. L. REV. 1309, 1332 (outlining the circumstances that led to the OTA being dissolved). Technically, Congress did not "abolish" the OTA, but it cut off all funding to the Office. See Legislative Branch Appropriations Act 1996, Pub. L. No. 104-53, § 112, 109 Stat. 514, 525-26 (1995).

${ }^{176}$ Lin, supra note 175 , at 1332.

177 See, e.g., Robert L. Glicksman \& Stephen B. Chapman, Regulatory Reform and (Breach of) the Contract with America: Improving Environmental Policy or Destroying Environmental Protection?, 5 KAN. J.L. \& PUB. POL’Y 9, 19 (1996) (criticizing elimination of the OTA).

178 See, e.g., Lin, supra note 175, at 1340-41; Rush Holt, Op-Ed, Reversing the Congressional Science Lobotomy, WIRED (Apr. 29, 2009, 10:40 AM), http://www.wired. com/wiredscience/2009/04/fromthefields-holt/.

1792 U.S.C. § 472(c) (2006) (stating that "[t]he basic function of the Office shall be to provide early indications of the probable beneficial and adverse impacts of the applications of technology and to develop other coordinate information which may assist the Congress"); id. $\S 472(d)$ (giving the Office itself the authority to decide what issues to explore and report).

${ }^{180}$ See Dean, supra note 3.

${ }^{181}$ See Jon M. Peha, Science and Technology Advice for Congress: Past, Present, and Future, 24 RENEWABLE RESOURCES J. 19, 21 (2006), available at http://repository.cmu.edu /cgi/viewcontent.cgi?article=1054\&context=epp (noting that in order to be useful to Congress, information must be in a format that "Congress can readily understand and apply”).

${ }^{182}$ See, e.g., id. at 20-22 (discussing accusations of bias lobbed at the Office of Technology Assessment and stating that "[t]he most likely way for bias to arise is in the selection of issues to be investigated”).

${ }^{183}$ See id. 
true when the issues are fairly politically sensitive. ${ }^{184}$ On the other hand, when the CSO reports on every bill that has passed the committee of jurisdiction, as well as on any requests that are made of it by the Chairman and the Ranking Member of relevant committees, the CSO itself cannot be accused of picking and choosing which issues to highlight. Instead, they merely would be a responsive body, helping Congress understand both the scientific background in the relevant area and the likely impact of the proposed legislation. It would, however, remain entirely up to Congress whether and how much weight to give to these reports. What Congress would not be able to avoid is the debate over the actual merits of the proposed legislation, either in the halls of Congress or on the campaign trail.

Additionally, the CSO-much like the CBO-would report not only on pending bills, but also provide a year-end report on how the bills previously enacted have actually worked in the real world. Educated predictions as to the effect that legislation will have are certainly a valuable tool for legislators to decide how to vote on a pending bill, but reporting and evaluating actual effects will help legislators decide whether to renew expiring legislation and will also serve as an annual self-check on the CSO itself. By cross-checking its predictions with actual outcomes, the CSO will be better able to fine-tune its evaluative function and insulate itself from any charges of partisanship.

\section{B. The Legislative Notice and Comment Process}

The creation of a Congressional Science Office, charged with evaluating proposed legislation for impact on science in the same manner that the CBO evaluates proposed legislation for its impact on the budget, would solve the first problem with current congressional decision making in the scientific arena: the lack of an independent, nonpartisan forum for discussing and evaluating proposals. However, two additional problems would remain - the lack of sufficient training in the subject matter of proposals to fully understand their scope ${ }^{185}$ and the lack of meaningful ability for the public to contribute to the debate and discussion of the proposals. ${ }^{186}$ Of course, the staff of the CSO would have to have scientific, technical, or engineering training - much like the staff of the CBO must have training in economics. However, with scientific knowledge proliferating and progressing at an incredible pace, it would be quite hard to hire enough people to cover all possible fields of scientific exploration. Even if such coverage were possible, it is likely that the knowledge of the Office's staff would grow stale with time.

Thus, the mere existence of the CSO and quality staff, while going a long way to improving the understanding of the scope and effect of the legislative proposals, would still be insufficient to keep up with the emerging or rapidly changing

${ }^{184}$ Id. at 21 (stating that much criticism was directed at the OTA following its negative review of the Strategic Defense Initiative-a top Republican priority).

185 See Holt, supra note 178.

${ }^{186}$ See supra notes 39, 54-56 and accompanying text. 
technologies. The CSO would have to look beyond its own internal expertise. This Article has already discussed that the CBO does just that by seeking input of independent experts of various political stripes in making its projections. ${ }^{187}$ While that approach is laudable, it is not sufficient in the context of evaluating the impact of legislation on scientific progress. Furthermore, if the CSO were able to pick its own experts - especially on highly charged issues (e.g., embryonic research, global warming, human subject research, etc.) - it could be open to the accusation of bias in its selection. ${ }^{188}$ If such an outcome were to come to pass, it would undermine the legitimacy of the CSO and its evaluations. Thus, in my view, the participation in evaluating the impact of proposed legislation on matters of science should be broader. Broader engagement would also address the current lack of meaningful opportunity for the public to participate in the shaping of legislative decisions. The question is how does one achieve broad participation that results in informative and valuable input into the ultimate product - the CSO's formal evaluation of legislative proposals?

One way to involve the interested and informed public in crafting legal language has been successfully tried in the administrative arena. The Administrative Procedures Act of 1946 (“APA”) ${ }^{189}$ required agencies to give notice to the public on proposed rules, to allow the public to comment on the proposal, and to consider the comments before issuing a final rule. "[N]otice-andcomment rulemaking provides several interrelated benefits. It allows all stakeholders in a regulatory decision to be heard before a decision is made and ensures that the agency responds to relevant comments." ${ }^{\text {"190 }}$ As the Fourth Circuit very recently pointed out,

The important purposes of this notice and comment procedure cannot be overstated. The agency benefits from the experience and input of comments by the public, which help ensure informed agency decisionmaking. The notice and comment procedure also is designed to encourage public participation in the administrative process. Additionally, the process helps ensure that the agency maintains a flexible and open-minded attitude towards its own rules, because the opportunity to comment must be a meaningful opportunity. ${ }^{191}$

${ }^{187}$ CBO, InTRODUCTION, supra note 28 , at 6 .

188 In other words, the focus of bias would move from the level of congressional committees to the level of CSO.

189 Pub. L. No. 79-404, 60 Stat. 237 (1946) (codified as amended in scattered sections of 5 U.S.C.).

190 Michael Kolber, Rulemaking Without Rules: An Empirical Study of Direct Final Rulemaking, 72 ALB. L. REV. 79, 86 (2009).

191 N.C. Growers’ Ass'n, Inc. v. United Farm Workers, 702 F.3d 755, 763 (4th Cir. 2012) (citations omitted) (internal quotation marks omitted). 
The agency, of course, "need not respond to every comment so long as it responds in a reasoned manner to significant comments received." ${ }^{192}$ In other words, the agency must simply show that it has considered the views of the public and came to a reasoned decision, even if that decision is contrary to views expressed in the comments. ${ }^{193}$ This process has been found to be so successful that there have been calls to export it beyond America's borders. ${ }^{194}$ However, the successes of the notice-and-comment procedure can be applied on the home front as well by transplanting it to the legislative arena.

Once a bill or proposal is referred to the CSO for an evaluation and report, the CSO would identify provisions that would potentially have an impact on scientific progress. It would then invite public comments on those provisions. Those most familiar with the underlying science, as well as the likely effect that the proposed legislation will have on the research in the field, would be able to convey their understanding to the CSO via a formal comment. Furthermore, because the comments would be open to the public at large (and not just to select scientists), comments would also be made centering on ethical implications of the legislative enactments or the research itself. In that way, the CSO would be able to present a full range of views of the scientific community, including any concerns raised about the propriety of certain methods and avenues of research. The CSO would serve as an aggregator and a filter for this commentary by evaluating, compiling, and summarizing it in a language accessible for the congressmen. It is Congress, however, that will ultimately decide what weight, if any, to give to the concerns and critique of the individuals and groups that have commented on the proposed legislation.

Of course, the process would not be identical to that in the administrative agencies. Administrative agencies' rules and actions can be judicially set aside for failure to follow the proper notice-and-comment procedure or for failure to consider comments submitted. ${ }^{195}$ No such sanction could be imposed on Congress if it or its own advisory body failed to fully consider the concerns of the public. After all, unlike administrative agencies that have only whatever authority delegated to them by Congress, Congress itself retains sovereign authority to enact whatever laws it deems fit (subject only to the constitutional constraints on its power). ${ }^{196}$ Nonetheless, though the courts would not be in a position to invalidate congressional laws as "inadequately considered or debated," the legislative notice and comment will still have a salutary and constraining function.

${ }^{192}$ U.S. Satellite Broad. Co. v. FCC, 740 F.2d 1177, 1188 (D.C. Cir. 1984).

${ }^{193}$ See Rodway v. U.S. Dep’t of Agric., 514 F.2d 809, 816-17 (D.C. Cir. 1975).

194 See generally Francesca E. Bignami, The Democratic Deficit in European Community Rulemaking: A Call for Notice and Comment in Comitology, 40 HARV. INT'L L.J. 451 (1999) (proposing that the European Community incorporate the basic features of United States notice and comment).

${ }^{195}$ See 5 U.S.C. § 706(2)(D) (2006) (stating that courts shall set aside agency actions that were arrived at "without observance of procedure required by law").

${ }^{196}$ Cf. Field v. Clark, 143 U.S. 649, 671-72 (1892) (holding that once Congress attests that the bill was properly passed, the judiciary will not inquire into the procedures). 
First, the notice-and-comment process will, of necessity, slow down some legislative activity because some time will have to be allocated to actually receive and evaluate the comments. Though it is true that Congress has not been a bastion of rapid and efficient decision making, an additional brake on legislation that may have a far-reaching negative impact on science, technology, and medicine is a positive thing. As Professor Lazarus points out, oftentimes slowing down such laws simply preserves the legislative and legal status quo ${ }^{197}$ - stability that is usually beneficial for scientific progress. ${ }^{198}$

Second, by combining broader public participation with the reasoned responses both from other members of the public submitting responsive comments, as well as from the CSO, the notice-and-comment mechanism will lead to a broader acceptance of the legislative outcome. ${ }^{199}$ By giving individuals a real voice in the legislative process, Congress will help grow confidence that, at least with respect to issues that turn on objective understanding of scientific realities and definitions, it has considered and properly weighed the objective evidence, even if a particular individual disagrees with the weight assigned to his or her own comments and arguments. ${ }^{200}$ Additionally, under an open notice-and-comment regime, the CSO is less likely to be lobbied or captured by special interest groups. If the CSO, like an administrative agency, is required by its rules to "respond[] in a reasoned manner to significant comments received," ${ }^{201}$ it will be less likely that a few influential individuals or groups would be able to sway the Office's views. Indeed, to the extent necessary, the Office can make the comments anonymous (beyond the educational and experience qualifications) so as to not be swayed by any personal connections or partisan leanings of the commenter. The fact that the CSO would not offer any policy prescriptions, but will limit itself only to analyzing legislation, will further insulate it from the danger of capture.

Third, and related to the second point, the ignoring of clear and specific criticisms and warnings issued by a neutral, nonpartisan body would serve as good fodder for intracongressional criticism, as well as campaign commercials. Much like candidates are now consistently criticized in campaign ads for disregarding the opinion of the CBO and voting for additional spending or tax cuts that have been scored as adding to the deficit, ${ }^{202}$ so too will candidates be criticized for adopting legislation that the CSO warned would lead to slowing of scientific progress. This will be an especially potent tool if in its "progress reports," the CSO reconfirms its initial predictions.

${ }^{197}$ Lazarus, supra note 73, at 634-35. vacuum.”).

${ }^{198}$ See id. at 634 ("The absence of legislative action does not create a disruptive legal

199 See Lin, supra note 175, at 1329-30.

200 See John Rawls, The Domain of the Political and Overlapping Consensus, 64 N.Y.U. L. REV. 233, 250 (1989) (arguing that fair policy-making processes tend to increase public acceptance of results).

${ }^{201}$ U.S. Satellite Broad. Co. v. FCC, 740 F.2d 1177, 1188 (D.C. Cir. 1984).

${ }^{202}$ See supra notes 162-163 and accompanying text. 
Finally, to the extent the courts consider the "legislative history" of any particular enactment, especially when applying the Chevron analysis ${ }^{203}$ to the administrative interpretations of the law (as was the case with Sherley $v$. Sebelius ${ }^{204}$ ) or when attempting to figure out whether a particular interpretation would be an "absurd result," subject to the rule of the Church of the Holy Trinity, ${ }^{205}$ the CSO reports would be of tremendous help. Courts will actually be able to see whether Congress was warned of the "absurd results" and whether it enacted legislation despite such warnings. ${ }^{206}$ Similarly, the courts (and administrative agencies) will be able to better evaluate whether the language and intent of the statute is indeed ambiguous or whether the particular problem, in all its details, was considered by Congress and a definitive decision reached.

\section{The Criticisms and a Response}

Had the proposed notice and comment followed by a full CSO report procedure been in place in 1996, the DWA may have encountered a different fate, though there are no guarantees that it would necessarily have been so. On one hand, it is true that the legislative vehicle to which the DWA was attached was considered, voted on, enacted by Congress, and signed by the President in fewer than forty-eight hours, thus leaving very little time for any, much less exhaustive, debate on the riders attached to the bill. ${ }^{207}$ Furthermore, given the "must-pass" nature of the bill and the background of the government shutdown that the bill was attempting to resolve, there was likely no appetite to debate the particulars.

Thus, the first objection is that it is unlikely that the process this Article proposes would have had much impact at that initial stage. Indeed, this criticism can be generalized to argue that the proposed process is unlikely to solve many problems and will accomplish little more than creating another government bureaucracy that will succeed only in the proliferation of reports that no one reads. While certainly the proposal is not a panacea to legislation gratuitously injurious to the progress of science, it is an improvement over the current process. In the case of the DWA, though Congress attached the rider to an emergency, must-pass bill, it does not mean that (a) the proposed system would have had no impact at all on the likelihood of DWA being enacted or (b) the DWA would have continued to survive, essentially unchanged, to the present day.

It is certainly the case that when operating under exceedingly narrow time constraints, the proposed CSO would not be able to engage in a full-blown notice-

${ }^{203}$ Chevron U.S.A. Inc. v. Natural Res. Def. Council, Inc., 467 U.S. 837, 842 (1984).

${ }^{204} 644$ F.3d 388, 394-97 (D.C. Cir. 2011).

205143 U.S. 457, 459-60 (1892).

${ }^{206}$ See Sedima, S.P.R.L. v. Imrex Co., 741 F.2d 482, 510 (2d Cir. 1984) (Cardamone, J., dissenting) (arguing that despite the majority's view that a different outcome would lead to "absurd results," "[t]he legislative branch fully considered the possibility of [such results] and took that risk advisedly"). Judge Cardamone's view was vindicated by the Supreme Court. See Sedima v. Imrex Co., 473 U.S. 479, 486-88 (1985).

${ }^{207}$ See supra notes 101-103 and accompanying text. 
and-comment period, analysis of comments received, and creation of a comprehensive report for congressmen to debate and consider. But such situations arise presently both in Congress and also in the administrative agencies. The CBO often has to work under very tight time constraints to produce cost estimates for last-minute budgetary compromises. ${ }^{208}$ Perhaps such reports are not as comprehensive as the reports that allow for more detailed study, broader consultations, and deeper reflection. But such reports are still given significant weight by congressmen and, eventually, the electorate. There is no reason to believe that the CSO would be unable to produce its own reports and estimates on an expedited basis, even if in those cases they would have to forgo the notice-andcomment mechanism. Similarly, administrative agencies also occasionally issue rules and regulations without engaging in the notice-and-comment process. The APA permits agencies to forego the process in "emergency situations." 209 This exception recognizes that though notice and comment is important, agencies do have their own expertise and can, in exceptional circumstances, be allowed to rely on that expertise alone. ${ }^{210}$ These exceptions are generally permitted only when the promulgated rule is temporary, with the permanent rule subject to the full scope of the APA procedures. ${ }^{211}$

${ }^{208}$ For example, the estimate for the "fiscal cliff" budget compromise was prepared on January 1, the very same day the Senate passed the bill. See, e.g., CONG. BUDGET OfFICE, ESTIMATE OF BUDGETARY EFFECTS OF H.R. 8, THE AMERICAN TAXPAYER RELIEF ACT OF 2012 (2013), available at http://www.cbo.gov/sites/default/files/cbofiles/attachmen ts/American\%20Taxpayer\%20Relief\%20Act.pdf (last visited Feb. 28, 2014). The actual text of the bill was only agreed upon the previous day. See Bill Summary \& Status, 112th Congress (2011-2012), H.R. 8, LIBRARY OF CONGRESS, http://thomas.loc.gov/cgibin/bdquery/z?d112:HR00008:@@@ (last visited Feb. 28, 2014); see also 158 CoNG. REC. S8592 (Dec. 31, 2012) (amendment by Senator Reid to strike all previously considered text and substitute the text of the amendment).

${ }^{209} 5$ U.S.C. $\S 553(\mathrm{~b})(3)(B)$ (2006) (permitting an agency to forego the notice-andcomment process "when the agency for good cause finds . . . that notice and public procedure thereon are impracticable, unnecessary, or contrary to the public interest"); Action on Smoking \& Health v. Civil Aeronautics Bd., 713 F.2d 795, 800 (D.C. Cir. 1983) (holding that promulgation of an order without notice-and-comment procedures under 5 U.S.C. $\S 553(\mathrm{~b})(\mathrm{B})$ is proper only if the agency concludes there is an "emergency situation[] wh[ere] delay would do real harm").

210 See Robert Orsi, Emergency Exceptions from NEPA: Who Should Decide?, 14 B.C. ENVTL. AFF. L. REV. 481, 507 (1987) (noting that in a situation where emergency environmental regulations are called for, the relevant agency would "exercise its own expertise in environmental matters").

${ }^{211}$ Am. Fed'n of Govt. Emps., AFL-CIO v. Block, 655 F.2d 1153, 1157-58 (D.C. Cir. 1981) (“[A]ny administrative action taken in a rare 'emergency' situation . . . need only be temporary, pending public notice-and-comment procedures. . . . [O]nce an emergency situation has been eased by the promulgation of interim rules, it is crucial that the comprehensive permanent regulations which follow emerge as a result of the congressionally-mandated policy of affording public participation ....”). 
Likewise, legislative riders on annual appropriations bills remain in effect only for so long as the underlying bill does, and because annual appropriations bills never last more than a year, neither do restrictions contained therein. Thus, though the initial restriction may have been enacted under emergency circumstances leaving no time for full public participation in the CSO process, nothing would prevent the CSO to conduct a full notice-and-comment procedure in anticipation of the rider potentially being renewed in a subsequent year. In emergency circumstances similar to the ones that attended the passage of the DWA, the initial report would potentially be truncated and somewhat superficial. In the long term, however, the process would still provide the benefits that this Article previously identifies. Relatedly, the CSO would be charged not just with making reports on pending bills, but also year-end estimates on the effect of all statutes presently in force (as they relate to science and technology). Thus, even if there were no opportunity to provide notice and comment at the time of a bill's initial consideration, there would still be an opportunity to comment on how the now-enacted bill has actually affected the progress of sciences, thus permitting Congress to reconsider the bill's scope when it comes up for reauthorization. Had this process been in place, the public would have had over a dozen annual opportunities to comment on the scope and effect of the DWA and explain the difference between parthenotes and embryos. Congress, presented with a formal report from the CSO would then have an opportunity to debate and rethink the renewal of the Amendment as originally written. Of course, Congress may well have remained unpersuaded, but at least congressmen would have to justify their approach to each other and/or their constituents.

The second objection to the proposed system-one that also casts doubt on the proposition that had the system been in place the DWA would have likely encountered a different fate-is that there are already ways for Congress to obtain detailed reports on matters of science and that an additional report-producing body would do little to change the legislative dynamic. After all, the National Institute of Health's Human Embryo Research Panel did issue a two-volume report on embryonic research, and that report did discuss the difference between parthenotes and embryos, ${ }^{212}$ yet Congress enacted the DWA anyway. This Article readily concedes that Congress could ignore the reports of the CSO just like it ignored the report of the Human Embryo Research Panel. However, the adoption of the Article's proposed system would not be simply duplicative of existing resources and advisory bodies.

This Article again refers to the CBO. By the time the Congressional Budget Act created the CBO, the Office of Management and Budget had been in existence for over half a century. ${ }^{213}$ Yet, Congress saw it fit to establish its own independent nonpartisan office. Though the Office of Management and Budget ("OMB”) is

${ }^{212}$ See NAT’L INST. OF HEALTH, supra note 92, at 61.

${ }^{213}$ See Michael J. Wieser, Beyond Bowsher: A Separation of Powers Approach to the Delegation of Budgetary Authority, 55 BROOK. L. REV. 1405, 1408 (1990). 
well respected, it is viewed as more partisan than the CBO. ${ }^{214}$ It is now the CBO, not its older sibling the $\mathrm{OMB}$, which has grown to be an authoritative arbiter on budgetary matters. ${ }^{215}$ Perhaps this stems from the fact that Congress is by its very nature bipartisan (even when a single party has a majority in both chambers), and therefore, each party has to try to accommodate the other to a certain extent, whereas the presidency is, of necessity, unipartisan, and the President need not accommodate anyone in selecting those of his advisors that are not subject to Senate confirmation. The same dynamic is likely to play out with the CSO. Though Presidents have had various bodies advising them on scientific and bioethical issues since 1974, each President has changed the scope and the focus of these commissions, thus giving the commissions a flavor of partisanship and allegiance to the appointing administration's priorities. ${ }^{216}$ In contrast, the proposed CSO would be charged with reporting on every bill having potential impact on science and technology, thus avoiding the perception that it is focusing on issues favored by a particular party or individual. Furthermore, the various presidential commissions were designed to recommend a specific course of action. Indeed, the present Presidential Commission for the Study of Bioethical Issues was created explicitly to "offer[] practical policy options," to the administration. ${ }^{217}$ Commissions with such charge can be perceived as having a stake in the political outcome rather than serving as a neutral evaluator of congressional proposals. That posture necessarily makes these bodies partisan, even if not in the traditional Republican or Democratic sense. Such a perception would undermine the value of the body to Congress and, therefore, to the legislative process.

Moreover, there is another reason that a Congress-based body for evaluating scientific issues is preferable to that based in the Executive Branch. As Congressman Rush Holt pointed out,

Congress needs access to unbiased technical and scientific assessments finished in a time frame appropriate for Congress, written in a language that is understood by members of Congress, and crafted by those who are familiar with the functions of Congress.

....

214 See Jonathan L. Entin, The Removal Power and the Federal Deficit: Form, Substance, and Administrative Independence, 75 KY. L.J. 699, 761 n.267 (1986) (stating that members of both parties view the OMB as more partisan and more "likely to distort its projections of the budget deficit in accordance with the chief executive's wishes”); Alan Fram, Despite GOP Laughter, Congress' Budget Office Gets High Marks With PM-CBO vs. OMB Numbers, AP NEWS ARCHIVE (Feb. 21, 1993), http://www.apnewsarchive.com/19 93/Despite-GOP-Laughter-Congress-Budget-Office-Gets-High-Marks-With-PM-CBO-vsOMB-Numbers/id-0cdd51362adc82226be3ecd79e86c657.

215 See Entin, supra note 214.

${ }^{216}$ See Nicholas Wade, Obama Plans to Replace Bush's Bioethics Panel, N.Y. TIMES, June 18, 2009, at A24.

${ }^{217} \mathrm{Id}$. 
$[\mathrm{M}]$ embers of Congress do not suffer from a lack of information, [but they] lack time and resources to assess the validity, credibility, and usefulness of the large amount of scientific information and advice [they] receive as it affects actual policy decisions. The purpose of the [former Office of Technology Assessment] was to assist members of Congress in this task. It both provided an important long-term perspective and alerted Congress to scientific and technological components of policy that might not be obvious. ${ }^{218}$

Simply put, scientific advisors based in the Executive Branch (or independent of political branches altogether) are not ideal because they are insufficiently familiar with congressional procedures, schedules, and language to serve congressional needs. Furthermore, what Congress needs is not merely the ability to find general information on a particular topic. That is easy enough to do. What Congress needs is an evaluation of the likely effect a specific bill is likely to have on scientific progress. Indeed, though the Human Embryo Research Panel discussed the nature of parthenotes, it did not discuss why the prohibition on the use of parthenotes might present significant problems. Thus, congressmen, even if they had read the Human Embryo Research Panel's report, would not have appreciated the full effect of the DWA.

Finally, though the various presidential commissions have done an admirable job soliciting views of a broad range of scientists, ethicists, patients, and others, they still lack the formal notice-and-comment format that this Article proposes. The formal notice-and-comment mechanism with an invitation to participate extended to every interested individual, rather than just to those that the commission finds to be worthy of attention, will improve both the legislative process itself and the public perception of and confidence in the process.

\section{CONCLUSION}

Mark Twain once quipped, "suppose you were an idiot. And suppose you were a member of Congress. But I repeat myself." ${ }^{219}$ This Article is somewhat less cynical about Congress. One of its real problems, among others, is not idiocy, but lack of digestible, objective, and timely information on complex scientific and technical issues. In today's political environment where even scientific issues are politicized and the public trust in legislators is at an all-time low, ${ }^{220}$ we sorely need a mechanism that provides unbiased assessment of legislative proposals while increasing public participation in the legislative process, diminishing the influence

${ }^{218}$ Holt, supra note 178 (emphasis added).

2192 Albert Bigelow Paine, Mark Twain, A Biography: The Personal and LITERARY LIFE OF SAMUEL LANGHORNE CLEMENS 724 (Harper \& Brothers 1912).

${ }^{220}$ Elizabeth Mendes \& Joy Wilke, Americans' Confidence in Congress Falls to Lowest on Record, GALLUP (Jun. 13, 2013), http://www.gallup.com/poll/163052/americans -confidence-congress-falls-lowest-record.aspx. 
of special interests, and educating legislators on the complex scientific and technical issues. An independent, nonpartisan, CSO modeled on the CBO, which would provide an opportunity for the experts and public at large to weigh in with comments on the likely effect of the proposed bills on scientific issues and would evaluate these comments and produce reports "written in a language that is understood by members of Congress, and crafted by those who are familiar with the functions of Congress," 221 would go a long way toward improving the legislative process and reducing damage that haphazardly considered legislation can inflict on scientific progress. Therefore, creating a legislative notice-andcomment process would improve legislation and public confidence and would have beneficial effects on science. While Congress may not always defer to the concerns raised by the commenters or the staff at the CSO, the improved quality of congressional debates-and the increased accountability that will come with forcing Congress to confront explicit warnings of the scientific community-will be a marked improvement over the current process of legislating in matters of science and technology.

\footnotetext{
${ }^{221}$ Holt, supra note 178 (emphasis added).
} 